Historic, Archive Document

Do not assume content reflects current scientific knowledge, policies, or practices. 

Dependalole

Trees, Fruilts, Shrirutlos

\section{Vimes and Plants}

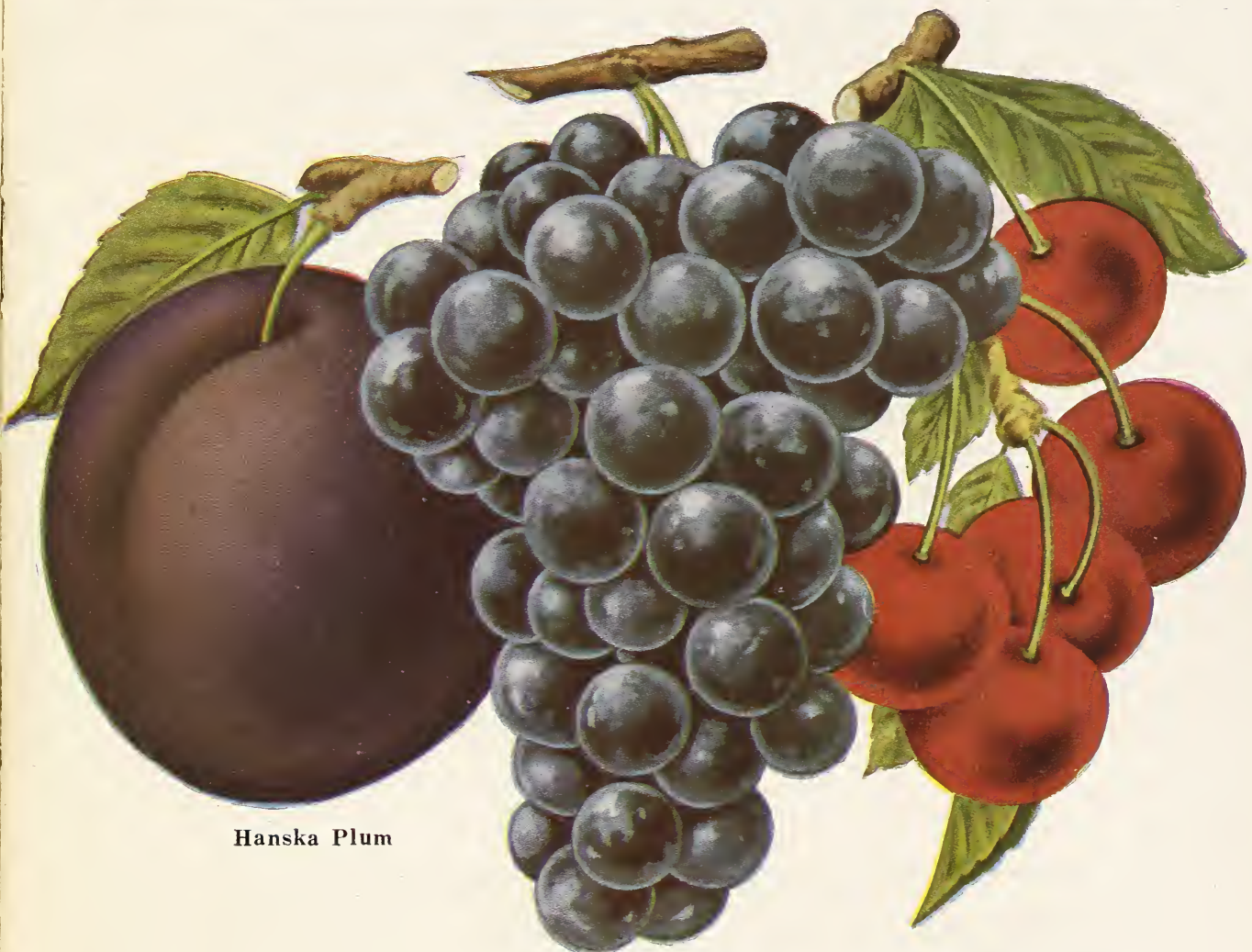

Moore's Early Grapes

Early Richmond Cherries

\section{The Dalmont Nursery}

GROWERS OF HARDY FRUITS AND SHRUBBERY

Adapted to $W$ est Texas and New Mexico

R. F. D. No. 2

Plainview, Texas 


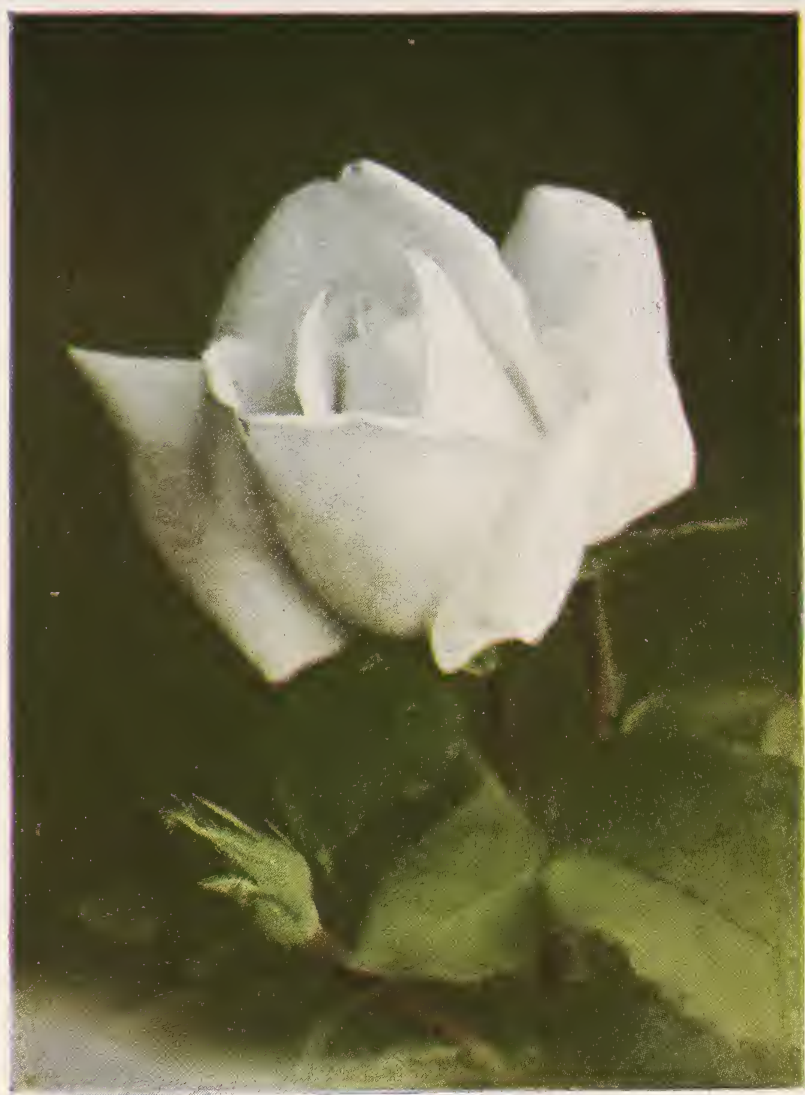

Frau Karl Druschki (Snow Queen)

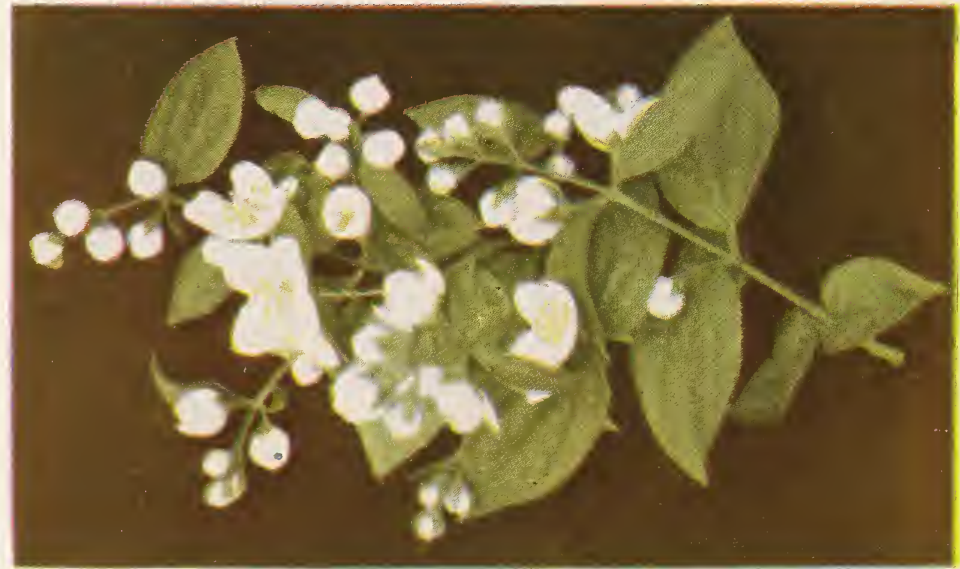

Syringa (Mock Orange) 


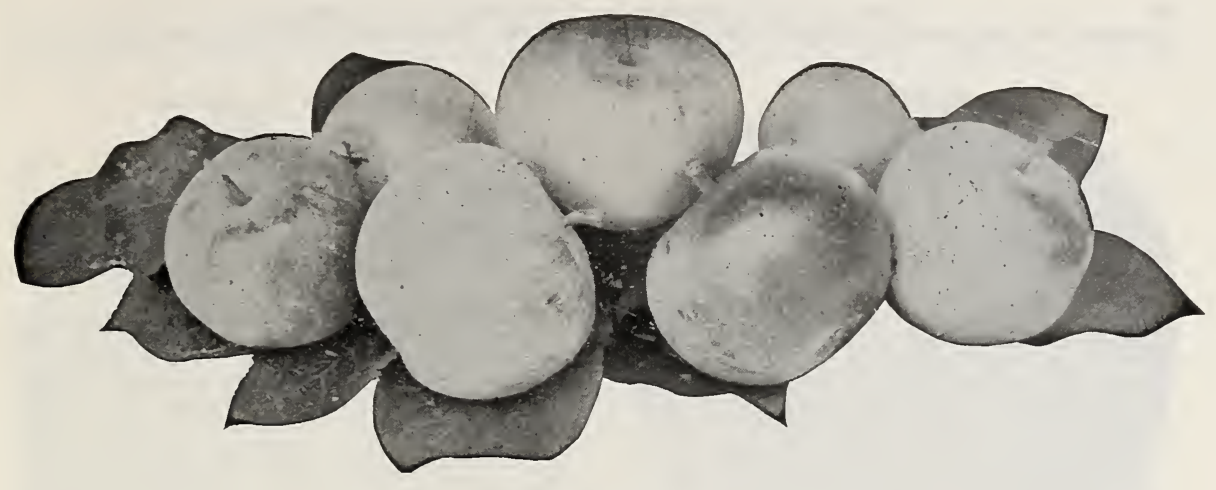

\section{Apples}

Taking into consideration its hardiness, productiveness and general commercial value, the apple stands at the head of the list of fruits. In selecting the most important varieties for cultivation, it has been our constant aim to secure only those of standard excellence, and in no instance to recommend a novelty without ascertaining its history from a reliable source.

\section{Summer Apples}

DLCHESS OF OLDENBURG $\rightarrow$ A large beautiful apple, roundish. Streaked red and yellow. Tender, juicy and pleasant. Tree a vigorous, fine grower and abundant hearer. Very hardy. September.

EARLY HARVEST-Tree healthy, vigorous and a good bearer. Fruit medium size, nearly round, somewhat flattened. surface smooth, clear, waxy yellow, rarely blushed; flesh tender, juicy, acid to subacid, flavor good. July.

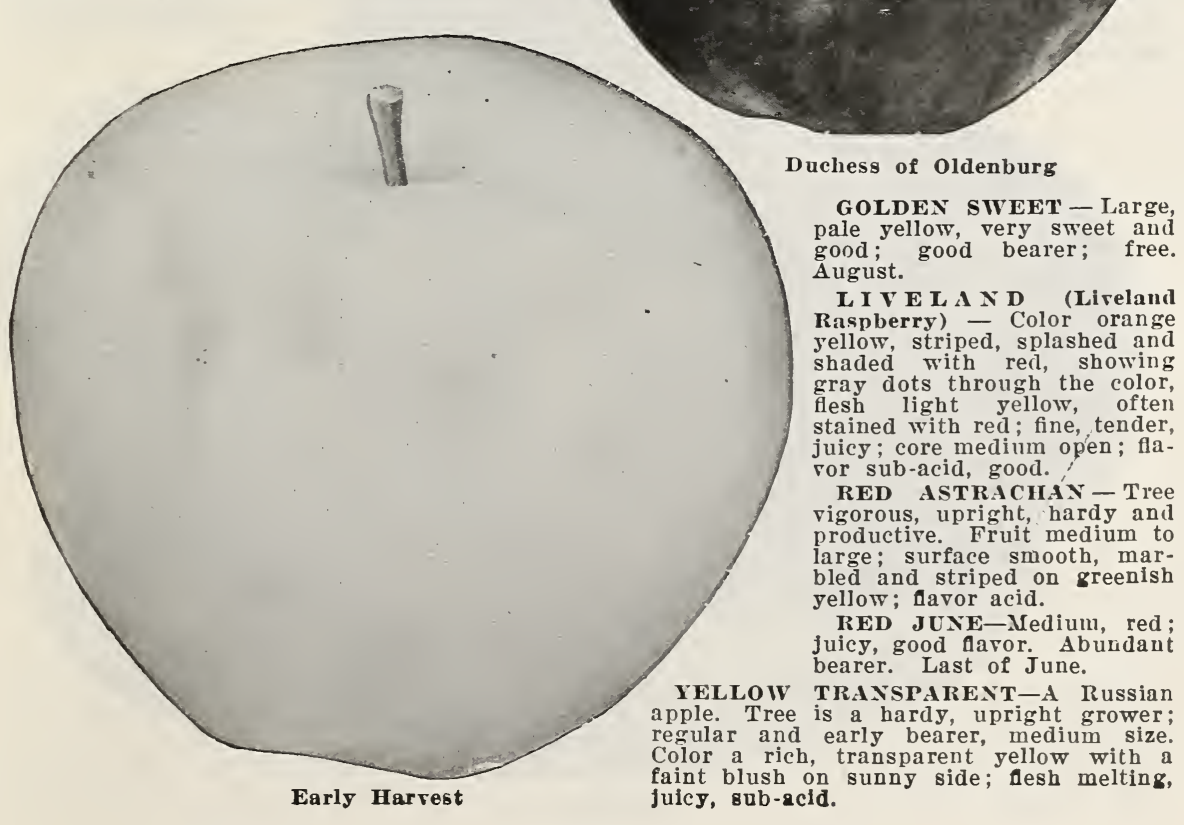




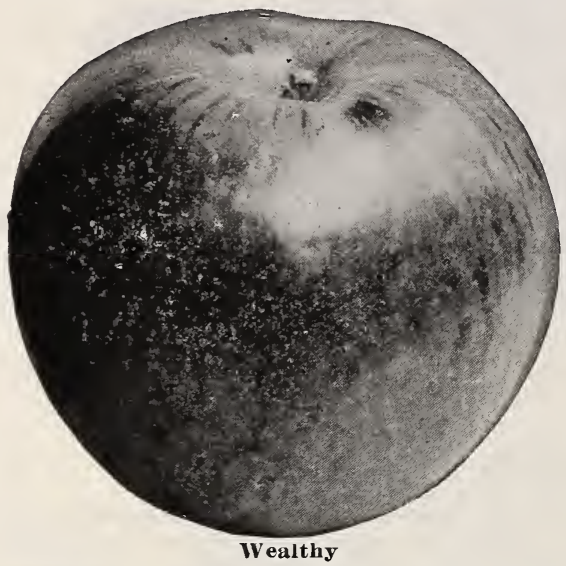

CHENANGO (Strawberry)-Rather large, oblong, conical, angular; whitish-yellow, striped and splashed with light crimson; flesh white, very tender, with mild, pleasant sub-acid flavor. A market and eating variety. Tree vigorous and productive.

\section{Autumn Varieties}

FAMEUSE (Snow Apple)-Medium size, roundish; crimson, sometimes striped in northern localities. Flesh snowy white: very tender, fine, juicy, mild, sub-acid; one of the finest dessert fruits. Hardy and prolific. Very popular. October and December.

MAIDEN BLUSH-Large, smooth, regular, evenly shaded red cheek or blush on a pale yellow ground; flesh white, tender, sprightly, with a pleasant sub-acid flavor; bears large crops; free. August to October.

RAMBO-Medium; yellow, striped with red. Fruit mild, tender, good. September to November.

WOLF RIVER - Extra large handsome; deep red; excellent for cooking. Extremely hardy in the north. Probably the largest red apple adapted to this region. September to November.

WEALTHY-Origin, Minnesota. Large, round; red; very handsome; fine quality; good grower. Perfectly hardy and most reliable. Very popular throughout the north. I.ong keeper in cold storage. October to January.

\section{Winter Varieties}

ARKANSAS BLACK - Vigorous, upright grower. Fruit medium to large; fine flavor, beautiful dark color, almost black; flesh yellowish, slightly sub-acid, crisp. One of the best for cooking. January to March.

You get a square deal in placing orders with us.
BALDWIN - Large, deep, bright red. Flesh juicy, crisp and of good flavor. Tree vigorous in the East and South, though not sufficiently hardy North. November and December.

ORDER TODAY

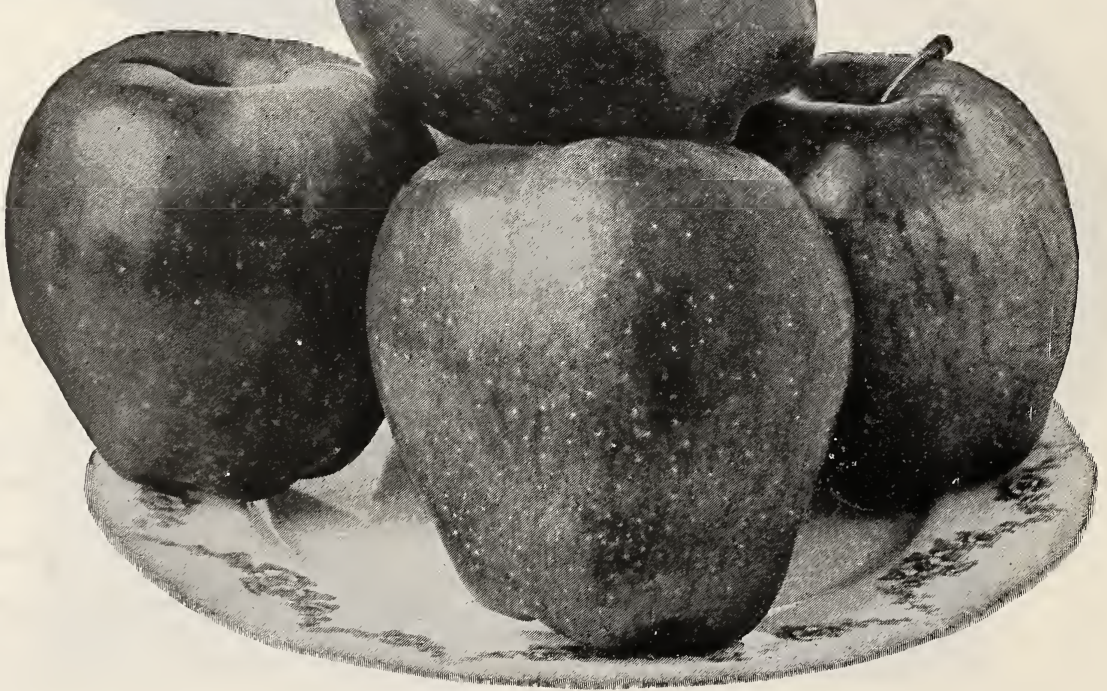




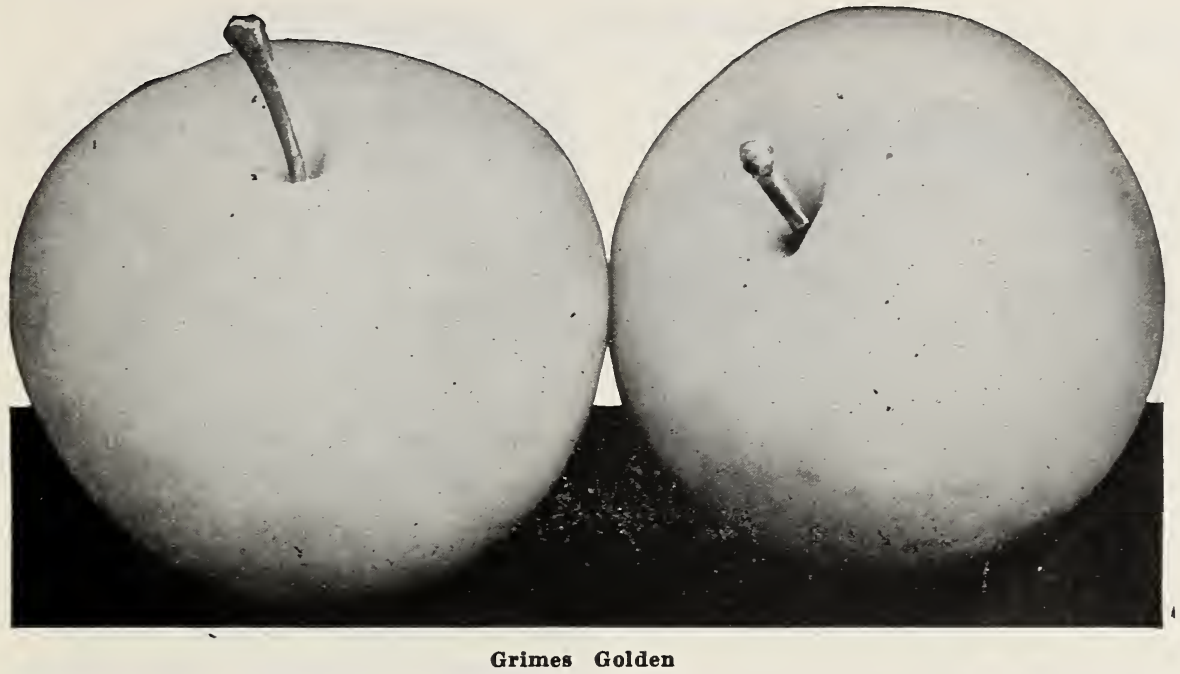

BEN DAVIS-Tree thrifty, upright grower of almost perfect shape. Fruit large, round, sometimes variable in form; surface smooth, often polished yellow, covered and splashed bright red; flesh white, tender, juicy; flavor sub-acid, not rich quality; only good for market and cooking. November to Spring.

DELICIOUS-Flourishes well in every state of the Union. Bears annually; great yielder; hangs well on trees. Trees very thrifty, long lived and extremely hardy. Fruit very large, nearly covered with brilliant, dark red; flesh

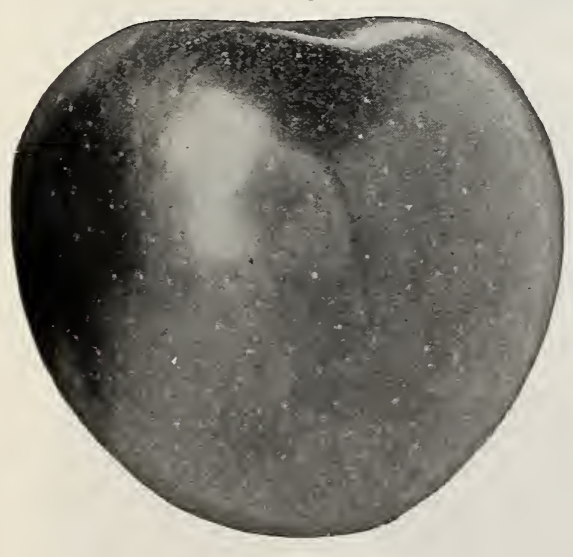

\section{Gano}

fine grained, crisp, juicy, melting and delicious; splendid keeper and shipper; should be in every orchard.

GANO-Fruit is bright red on rellow ground, with no stripes; large, oblong, surface smooth, polished; dots minute; basin shallow, sometimes deep; eye large, carity deep; brown in color; stem medium to long; core medium. Tree healthy, vigorous and prolific bearer. January to April.

GRIMES GOLDEN-This is one of the most popular apples in cultivation. Tree strong, thrifty grower. Fruit medium or above, cylindrical; regular surface, yellow reined, russeted; flesh yellow. firm, very fine grained, juicy; flavor sub-acid; quality rich. For dessert, cooking and market. Norember and December.

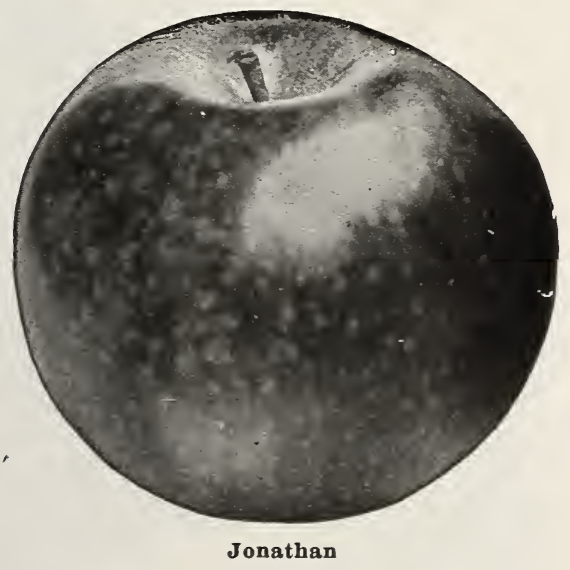

JONATHAN-Tree of rather slender growth and spreading habit; fruit medium or above in size, round or oblong: surface very smooth, waxy yellow, often wholly covered with brilliant red; flesh whitish yellow, tender, very juicy; for dessert and cooking; quality best. October and Norember. 


\section{Winter Varieties-Continued}

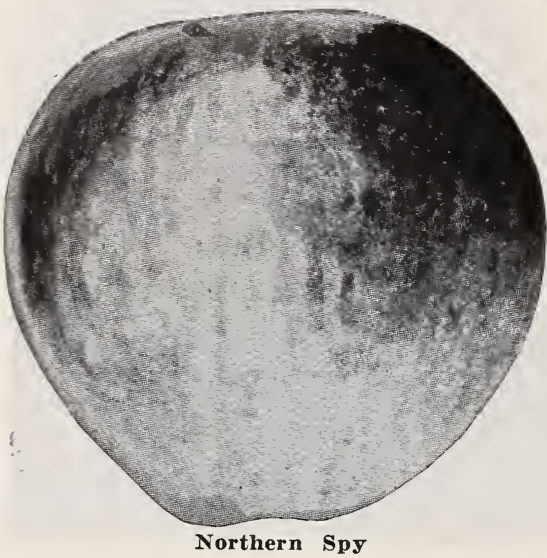

MAMMOTH BLACK TWIG-Extra large size, round, skin smooth, yellowish, covered with deep red, the general effect being dark red; flesh tender, tinged with yellow, crisp, sub-acid, aromatic, of excellent quality in every way. Tree vigorous, healthy and bears when quite young; very prolific.

MeINTOSH (McIntosh Red)-Medium large, polished, smooth, yellow, nearly covered with brilliant crimson; beautiful; flesh snow white, crisp, very tender, aromatic; sub-acid; very good quality. Resembles Fameuse type, but
Is larger and more hardy. Tree vigorous, with spreading head; a good annual bearer; popular in northwest. November to February.

NORTHERN SPY-Large, roundish, slightly conical; striped with sunny side purplishred; flesh white and tender, with mild, rich, spicy flavor. An old favorite and one of the best all-around apples grown. Tree is a strong, upright grower, head very compact and should be opened up by pruning to admit air and light. December-June.

NORTHWESTERN GREENING-Fruit medium to large, averaging from seven to eight ounces each and very uniform in size. Color greenish yellow, flesh juicy, firm and fine grained. Very fine quality and flavor. Tree is very hardy and a thrifty grower, an early and continuous bearer. One of the longest keepers known. January to spring.

PATTEN'S GREENING-Duchess seedling; very large; flavor pleasant, sprightly, subacid. Superior for cooking. December to February.

RAWL JANET-Tree good grower, not so large as some; fruit medium; somewhat conical, regular; surface smooth, mixed and striped on yellow and green; flesh yellowish, crisp, fine grained, juicy; flavor sub-acid; quality good to very good. For dessert, kitchen, market and cider. November to spring.

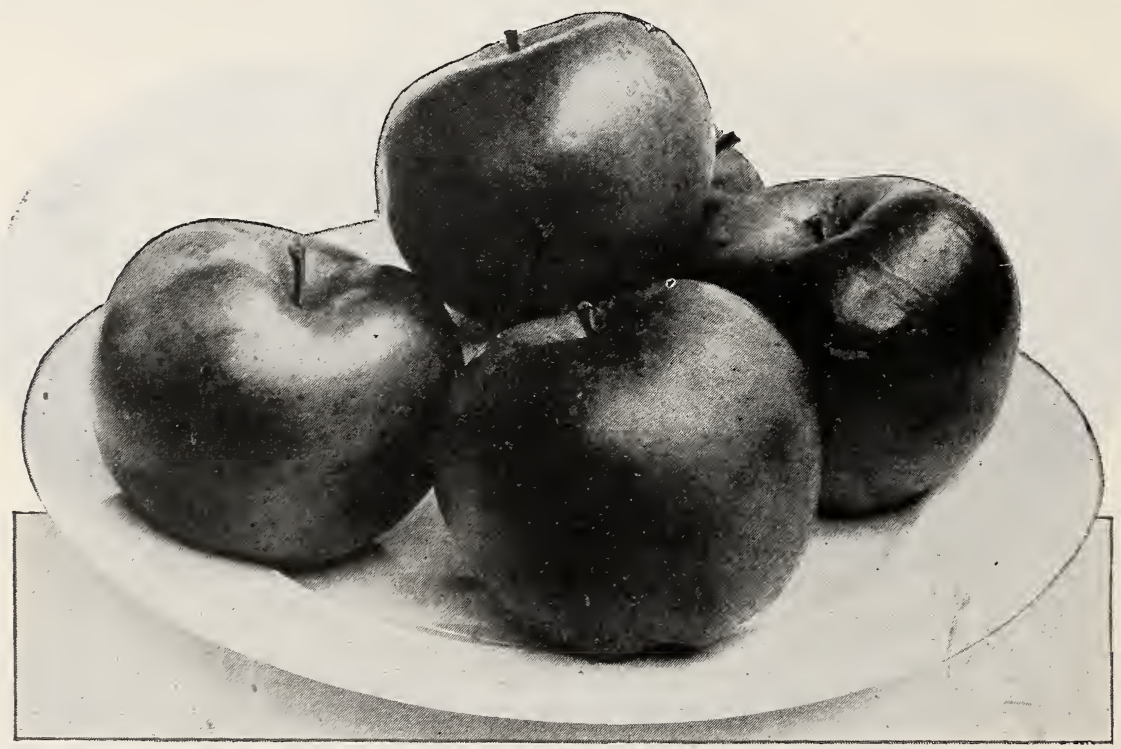




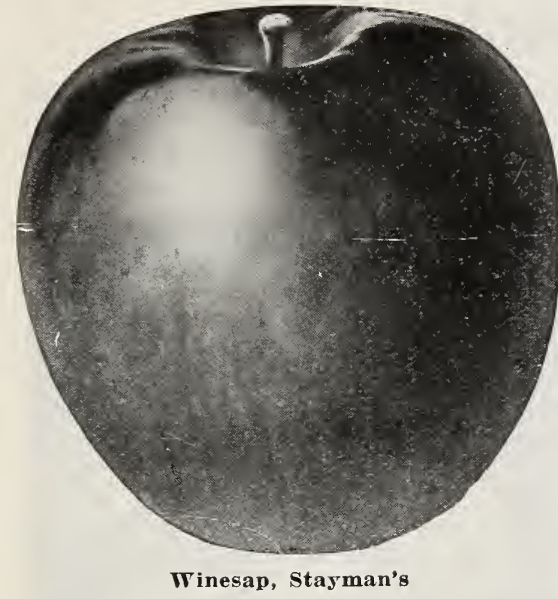

RHODE ISLAND GREENING - Large, greenish yellow, tender, juicy and rich, with rather an acid flavor; growing strong and spreading, and an abundant bearer, but drops prematurely in the West, and should be gathered early if planted at all. November and December.
ROME BEAUTY (Gillett's Seedling)-rarge, vellow, striped with red, flesh juicy, crisp, sub-acid, tree moderate grower. October to necember.

TALMAN SWEET-Medium size, pale yellow, slightly tinged with red; firm, rich and sweet; excellent for preserving; tree vigorous, rery hardy and productive. November to April.

WINESAP (Stayman's) - Large, roundish, deep red; medium quality; keeps well; tree a fair grower and good bearer. December to May.

WINTER BANANA-A highly prized and valuable market sort. Beautiful yellow fruit; flavor exquisite and very tempting; highest quality. Productive. Reliable growers represent it to be hardy North. Very popular for dessert.

YORK IMPERIAL-Tree moderate grower and productive, fruit large, lop-sided; surface smooth; color mixed bright red on yellow ground; flesh yellowish, tender, juicy, flavor mild sub-acid; quality very good; for market, table, kitchen. November till spring.

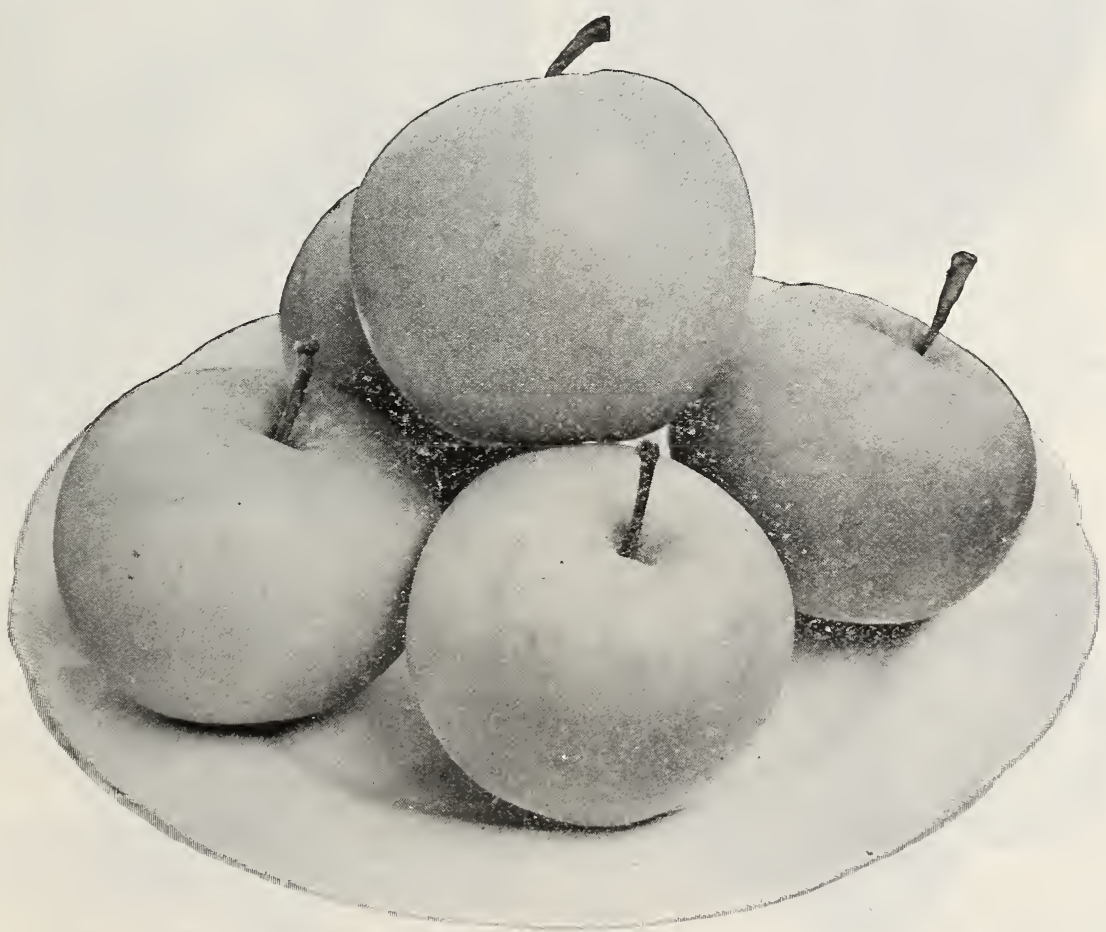




\section{Crab Apples}

A few years ago the crab apple was thought fit only for cider, preserves and jelly, but there are varieties now that command a good price on the market for dessert purposes. They are ornamental when in bloom and when loaded with their highly colored fruit.

FLORENCE - Large, handsome ; crimson, splashed with darker red; prolific, valuable. September.

IIYSLOP-Tree a moderate grower, making a bea utiful shaped, thrifty tree; bears young; fruit large, nearly round, flattened at the ends; skin smooth, color dark rich red on yellow ground; flavor very good.

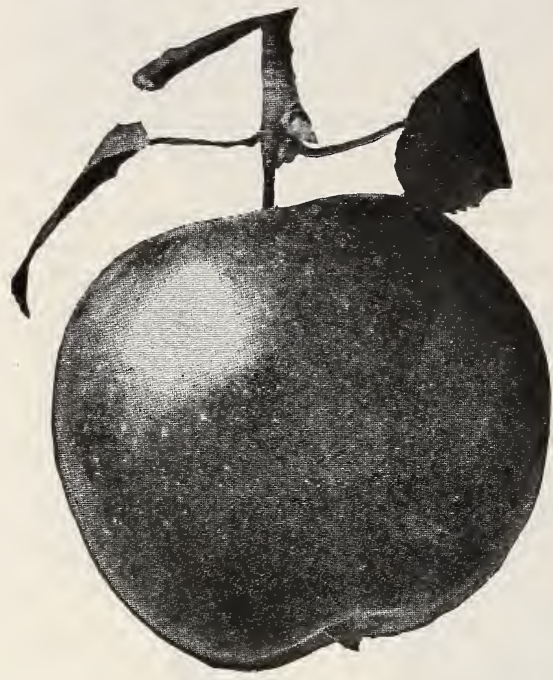

Hyslop

MARTHA-This is one of the best. The vround is bright yellow, nearly over-spread with light bright red. Of good size.

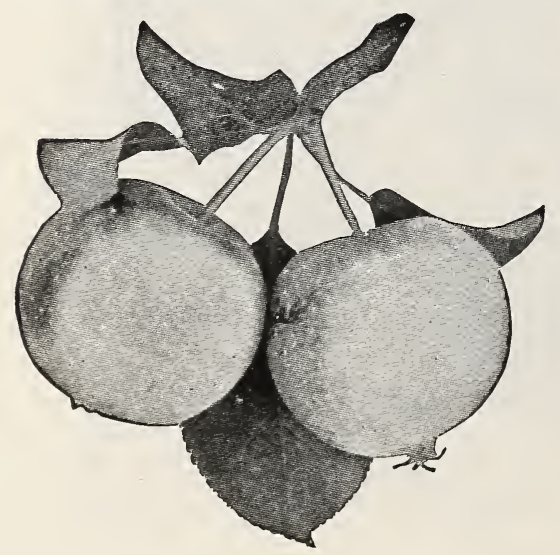

Whitney

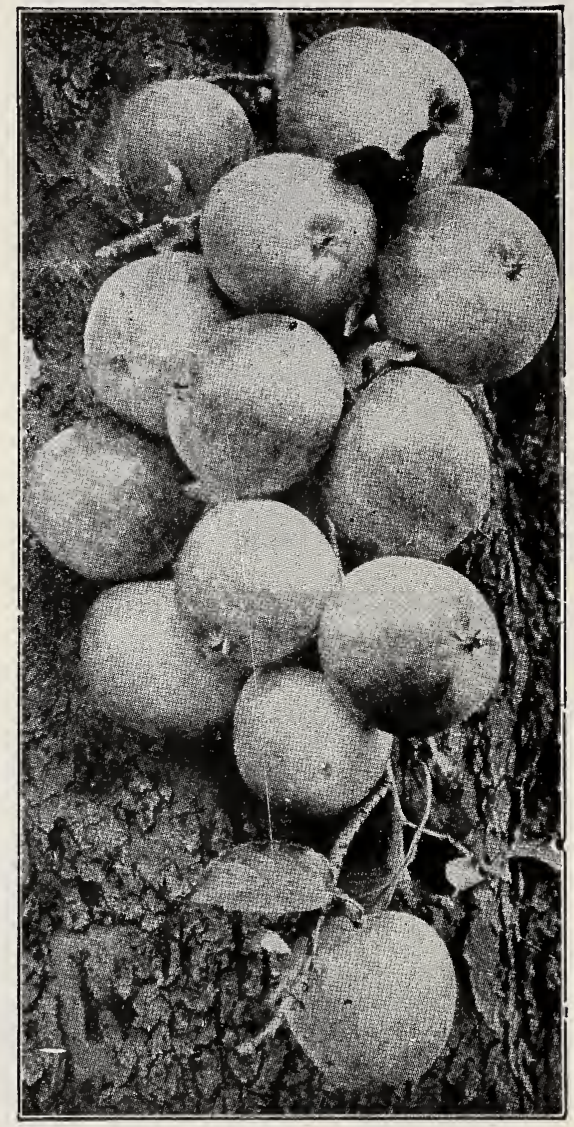

Transcendent

RED SIBERIAN-Large, round, brilliant red on a pale yellow ground; flesh acid and greatly esteemed for preserves and jellies.

TRANSCENDENT-A very strong grower, making a large, beautiful tree; an early and abundant bearer, fruit large, round, skin smooth, color rich yellow, shaded with red. August and September.

WHITNEY-Tree thrifty, upright grower; fruit large, skin smooth, striped and splashed with carmine; flesh firm, juicy, of pleasant flavor. One of the very best. August.

YELLOIV SIBERIAN-Small, round; yellow; flesh yellowish and acid; popular on market for jellies. Tree vigorous and hardy. September. 


\section{Pears}

The soil should be rich and well cultivated. A pear orchard should not be permitted to "go to grass." They should be pruned every year, dwarfs especially. Dwarfs should have low heads and be trained in a pyramidal form, one-half of the previous season's growth being cut off each spring.

Pears succeed best on rather steep hillsides. Plant pears midway on the slope, puttiug something else on the upper and lower sections. Cultivate sparingly, so as to induce a rery slow growth, and let blue grass take the land before the trees come into fruitage. IVhen bliglit appears, cut off the affected parts at once and burn them; cut six inches below the lowest blight, to insure taking all infected sap.

\section{Early Varieties}

I3.IITLETT-Large size, with beautiful blush next to the sun; buttery, very juicy and high flavored; bears early. August and September.

CIAPP'S FAVORITE-Large obovate : skin thin, pale yellow marked with pale crimson and lawn colored dots; flesh white. ine grained, juicy, buttery, rich, melting and sweet. Very vigorous, upright grower. August and early September.

WILDER EARLY-One of the very earliest pears. Size medium, greenish yellow, with a brownish red cheek and numerous dots; flesh white, fine grained, melting, excellent. Always find a ready sale in market. Largely grown by com. mercial orchardists. Tree bears good crops early and annually. December aud September.
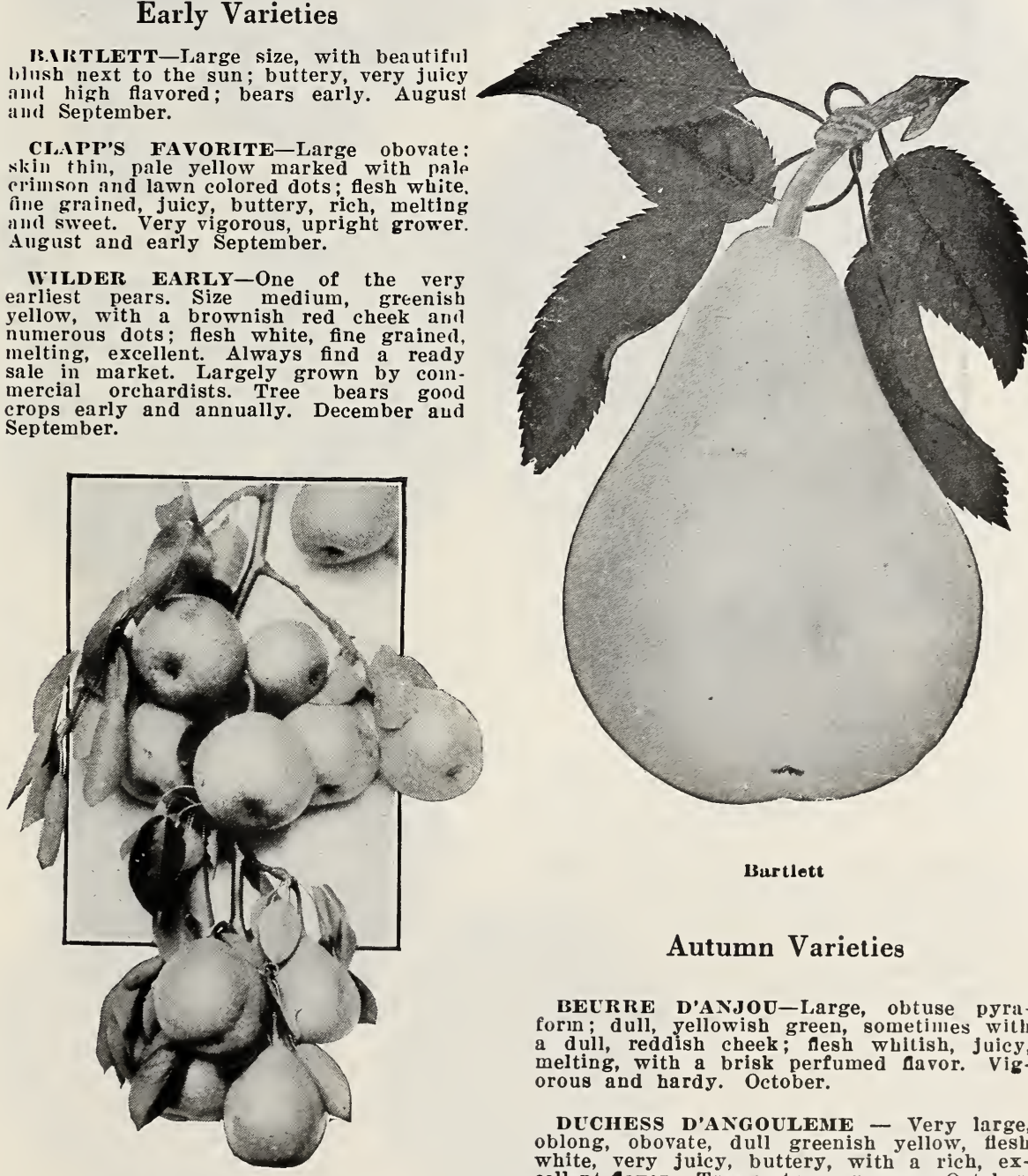

Burtlett

\section{Autumn Varieties}

BECRRE D'ANJOU-Large, obtuse pyraform: dull, yellowish green, sometilles with a dull, reddish cheek; fesh whitish, Juicy, melting, with a brisk perfumed Aavor. Vigorous and hardy. October.

DUCHESS D'ANGOULEME - Very large, oblong, obovate, dull greenish yellow, flesh white, very juicy, buttery, with a rich, exBeurre D'Anjou cellent flavor. Tree a strong grower. October. 


\section{Autumn Varieties-Continued}

FLEMISH BEACTY-Iarge, beautiful, juicy, melting, rich and fine; good bearer; one of the hardiest and does well nearly everywhere. September and October.

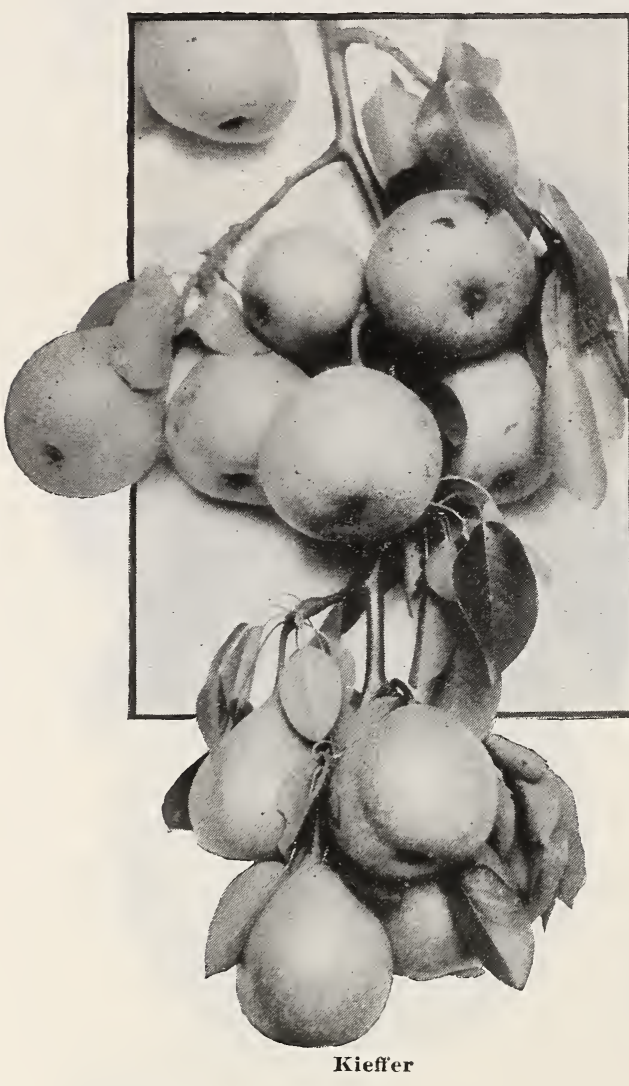

KIEFFER-Large; golden yellow, often blushed in the sun; juicy and melting. One of the best for canning and preserving; the most profitable to grow. Tree healthy, hal ${ }^{\prime}$ y and vigorous. Does not succeed on quince, therefore no dwarfs should be planted. Kieffer receives more praise and condemuation than any other. It is liable to overbear, therefore special pains should be taken to thin the fruit.

SECKEL-Small, skin rich, yellowish brown; flesh very fine grained; sweet, juicy and pleasant. Best for its size. September and October. 


\section{Plums}

The plum delights in a cool, not too dry situation, and good rich soil. Plant trees 10 to 15 feet apart, in rows. The varieties we offer have been thoroughly tested, and are standbys. These may be relied upon to furnish crops of this profitable and delicious fruit.

\section{European Varieties}

BRADSIAT-Fruit large; dark violet red, fesh yellowish green; juicy and pleasant; productive. Vigorous. Middle of August.

DAMSON (Europe)-Small; black, with thick blue bloom; free; flesh juicy, but rather tart; best for kitchen and market. Tree enormously productive and hardy. September.

GERMAN PRUNE-Very large, long, oval; purple, with a thick blue bloom; flesh green, firm, sweet, pleasant and separates freely from the stone. Tree bears enormous crops, hanging late; vigorous. September.
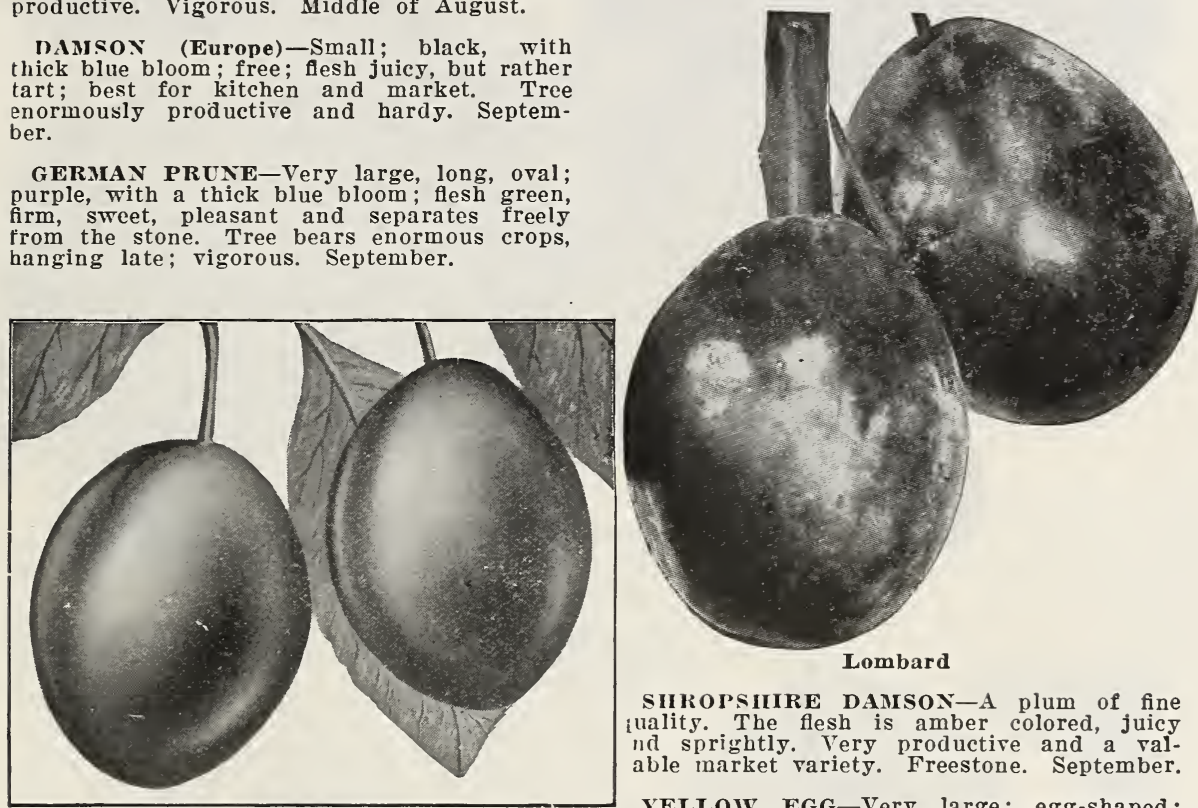

SIIROPSIIIRE DAMSON-A plum of fine iulity. The flesh is amber colored, juicy nd sprightly. Very productire and a ralable market variety. Freestone. September.

YELLOIV EGG-Very large; egg-shaped ; excellent for cooking; good and productive; rigorous. Last of August. Splendid variety for nearby market.

sh yellow: semi-cling; flesh juicy, rich and delicious; one of the best for dessert. Tree slow grower. September.

LOMBARD-Tree vigorous, hardy and productive: fruit of medium size, roundish oval, slightly flattened at the ends; skin of a delicate violet-red, paler in shade; flesh deep yellow, juicy and pleasant. August.

SHIPPER'S PRIDE-Size large; color dark purple; flesh firm and excellent. September.

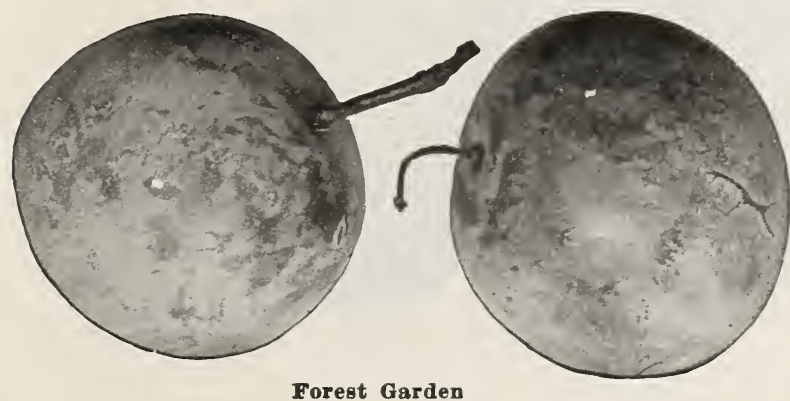

Native Varieties

COMPASS CHERRY-Small, purplish red, with large pit, flesh yellow and very good for cooking. The original cross of Miner Plum and Sand Cherry.

I) SOTO-Resembles Miner in form and color, but two weeks earlier. Fine for eating or canning. Tree a moderate grower; bears young and profusely; hardy north. Is best planted on moist rich ground and the fruit thinned. Use this rariety for fertilizing.

FOREST GARDEN - A strong growing tree; needs a little attention to keep tree in sbape to aroid splitting and breaking of limbs. A profuse bearer and perfectly hardy; nearly round, mottled red and jellow, rich and sweet. August. 


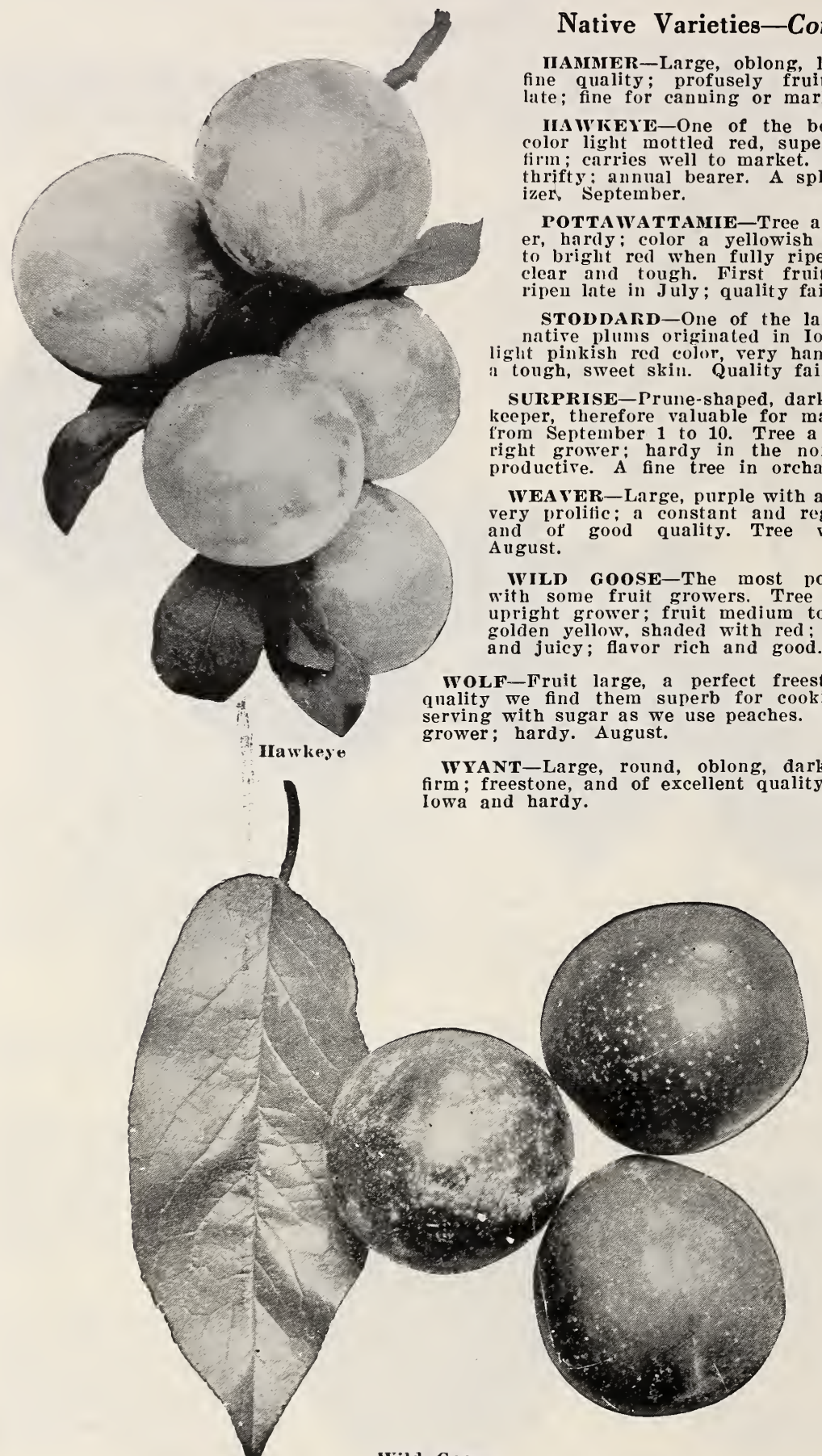




\section{Japan Varieties}

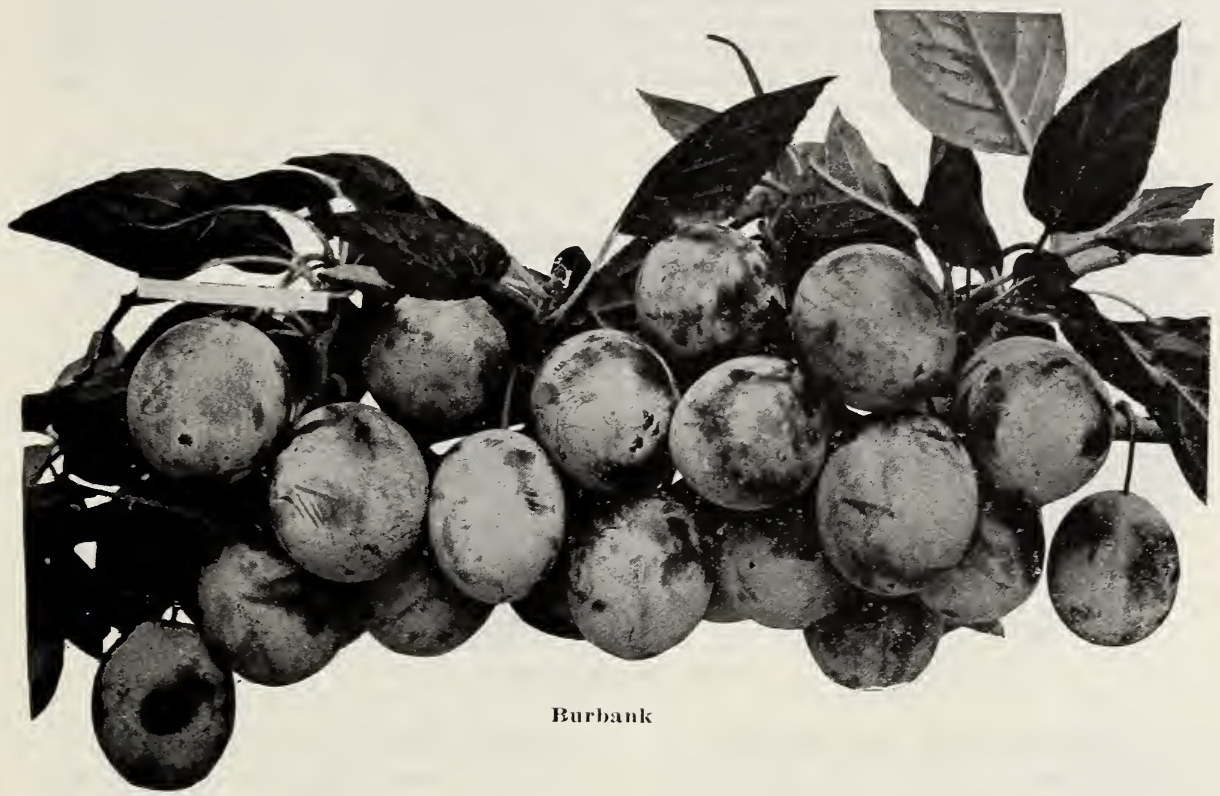

ABUNDANCE-Large, roundish ; freestone; amber, turning to a rich cherry color with a whitish bloom: flesh light yellow, juicy, tender, sweet and excellent, vigorous and very productive. August.

BURBANK-Large, nearly globular; clear cherry red with thin lilac bloom; flesh deep yellow: rich, very sweet, with a peculiar and agreeable flavor. Vigorous and a very early bearer. Last of August.

RED JUNE-The best Japan plum, ripening before Abundance. Medium to large; deep vermilion-red, with handsome bloom; flesh light lemon-yellow, firm; moderately juicy; fine quality. Tree upright, spreading, vigorous and hardy; productive.

WICKSON-A remarkably handsome, very large, deep maroon red plum.

\section{Hybrid Varieties}

HANSKA-Beautiful color, bright red, with heavy bloom; flesh firm, yellow and of good quality; fragrant; apricot flavor; tree tall, rapid grower; pit small.

OPATA-Flesh firm, greenish with pleasant flavor. Pit small; season early; is strong grower and heavy bearer.

SAPA-Much like Oxheart cherry, dark flesh and juice. Fine quality. Five-foot trees at three years bear 1 to $11 /$ bushels and keep it up. Every home in the country should possess from one to a dozen of these wonderful trees.

TOKA-Similar to the Hanska of same parentage; tree remarkably strong and rigorous grower, making a model tree; early and heavy bearer of handsome fruit.

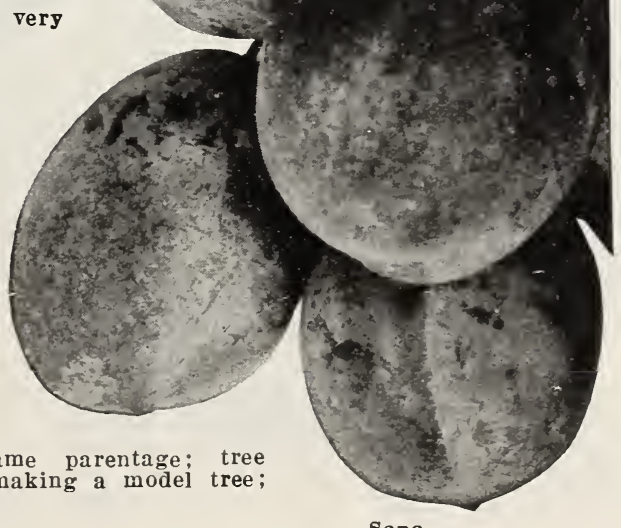




\section{Cherries}

Cherry culture has been a success when proper attention has been given to the selection of varieties and their culture. The hardy, thrifty varieties of the Morello type may be freely planted with confidence of profitable results. The cherry tree should be planted in a naturally dry soil or the soil should be well drained, so that water may not remain near the roots for any considerable time.

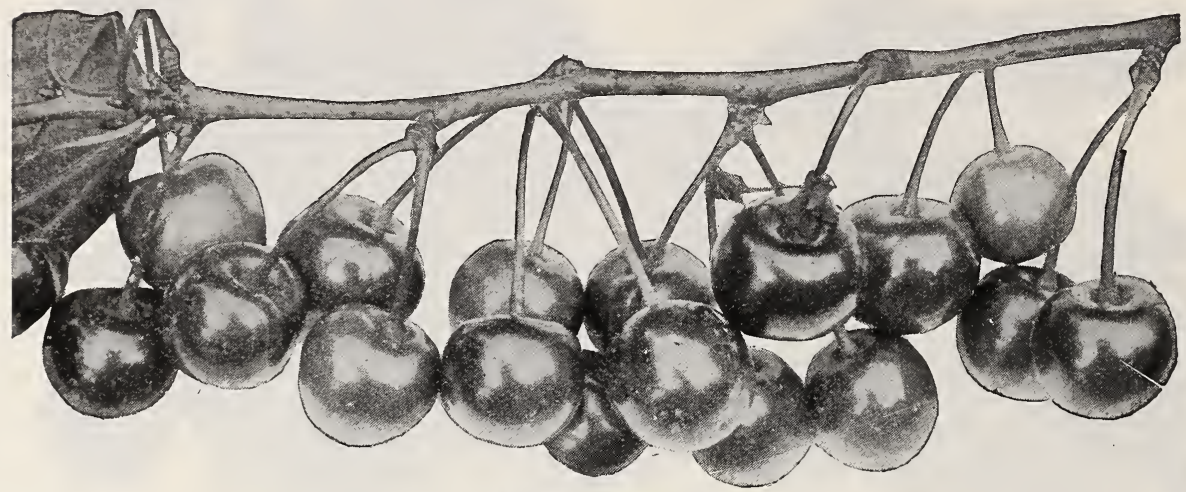

Large Montmorency

Duke and Morello (Sour)

DYEHOUSE-This variety partakes both of the Morello and Duke wood and fruit. A very early and sure bearer; ripens a week before Early Richmond, is of better quality and productive. Free. May and June.

EARLY RICIMOND-Everywhere the most popular. Tree strong, thriftr grower, making a large, symmetrical head; fruit medium size, dark red, melting, juicy; sprightly acid flavor and especially valuable for cooking purposes: tree an early and abundant bearer. Season last of May and first of June.

ENGLISH MORELLO-Tree moderate grower, hardy; an early and great bearer: the most valuable of the late varieties. Fruit large, round; skin dark red, becoming nearly black when fully ripe; flesh dark red, tender, juicy and of a pleasant sub-acid flavor whes fully ripe. July.

LARGE MONTMORENCY-A fine, large, light red cherry of the Richmond class, but larger and more solid; a more upright grower, equally hardy and productive. Second only to Early Richmond in value. Ripens ten days later.

WRAGG-Originated in Iowa. Medium to large in size, long stem, dark purple when fully ripe. A variety well adapted for the prairie regions of the Northwest. Appears identical in tree and fruit with English Morello, but is claimed to be a new variety. Valuable late cherry. July.

\section{Heart and Bigarreau (Sweet)}

BLACK TARTARIAN-Very large, bright, glossy black; half tender, juicy, rich and fine. Tree a rapid grower and good bearer. Iast of June and first of July.

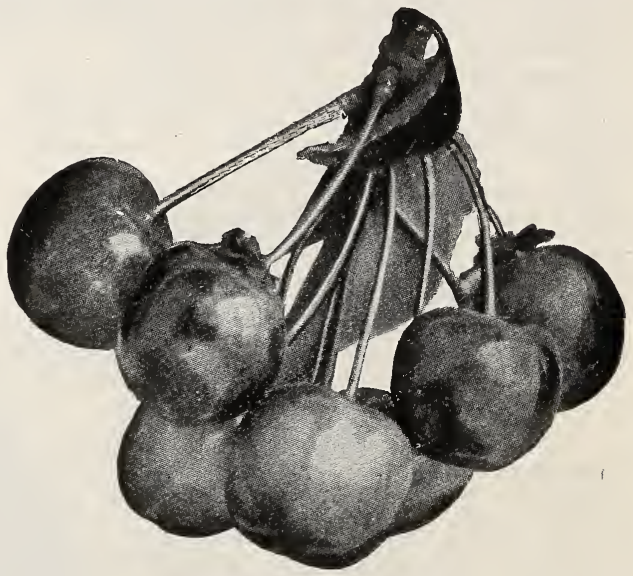

Early Richmond

GOVERNOR WOOD-Large; light yellow and bright red; nearly tender, juicy, sweet, rich and delicious. Tree vigorous and productive. Middle to last of June.

WINDSOR-The fruit is large, flesh remarkably firm, sweet and of fine quality. Tree hardy and prolific. Middle of June. 


\section{Peaches}

Peach trees should be planted 16 to 18 feet apart. Cut weak shoots back about onehalf and strong ones about one-third, but see that there is left a sufficient supply of fruit buds. Sickly and superfluous shoots should be cut out clean. The fruit is borne on wood of last season's growth, hence the necessity of keeping up a good supply of vigorous annual shoots all over the tree. Young trees should be well mulched every spring.

ADMIRAL DEWEY (F.)-A perfect freestone, of fine size, form and color, with delicious yellow flesh that is yet firm enough to ship well. The tree is a strong, hardy, symmetrical grower and produces well. The best early yellow freestone. July.

ALEXANDER (S. C.)-Large size, handsome and regular in form, with deep maroon shade, covered with the richest tint of crimson, rich and good in quality, with a vinous flavor; adheres to the stone. Last of June.

BOKHARA (F).-Raised from seed procured in Bokhara, Asia. It has been fruited in the Northwest for years and found to be one of the hardiest peaches known there. Tree has stood 28 degrees below zero with but little injury to the tips, and produced fair crops. Fruit, large, yellow, with red cheek, of good quality, perfect freestone; skin tough, a fine shipper. August.

CIIAMPION (F.)-The earliest freestone and a first-class shipper. Bears full crops when others fail. In comparison with the bountiful yield of all of the best kinds, it is of all of them the champion. Size large, flavor delicious, juicy, sweet, rich, excelling all other varieties; very haudsome in appearance, creamy white with red cheek; very hardy; season earliest.

CRA WFORD'S EARLY (F.)-Fruit very large, oblong; skin yellow, with a fine red cheek; tlesh yellow, juicy, sweet and excellent. Wonderfully productive and hardy. Freestone. Last of August.

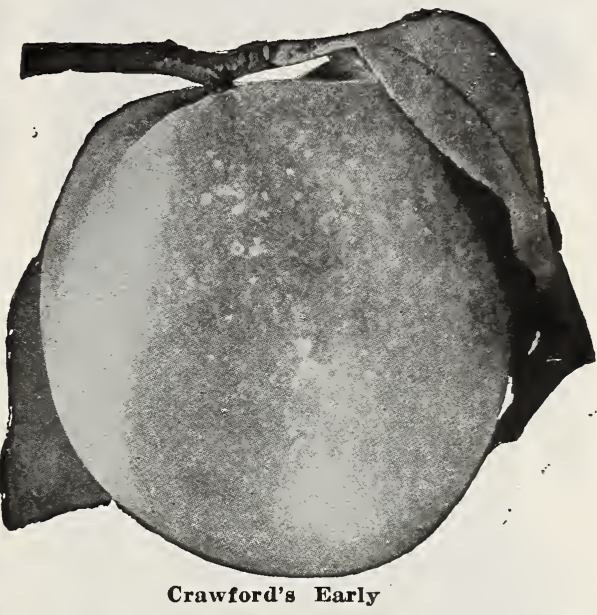

CRAIVORD'S LATE (F.)-Fruit of the largest size; skin yellow or greenish yellow, with dull red cheek; flesh yellow; productive. One of the finest late sorts. Freestone. Last of September.

CROSBY (F.)-Rich orange yellow with blush, freestone, pit small. Flesh yellow, juicy and sweet. Tree low, spreading; willowy nabit of growth. Ripens before Crawford's Late.
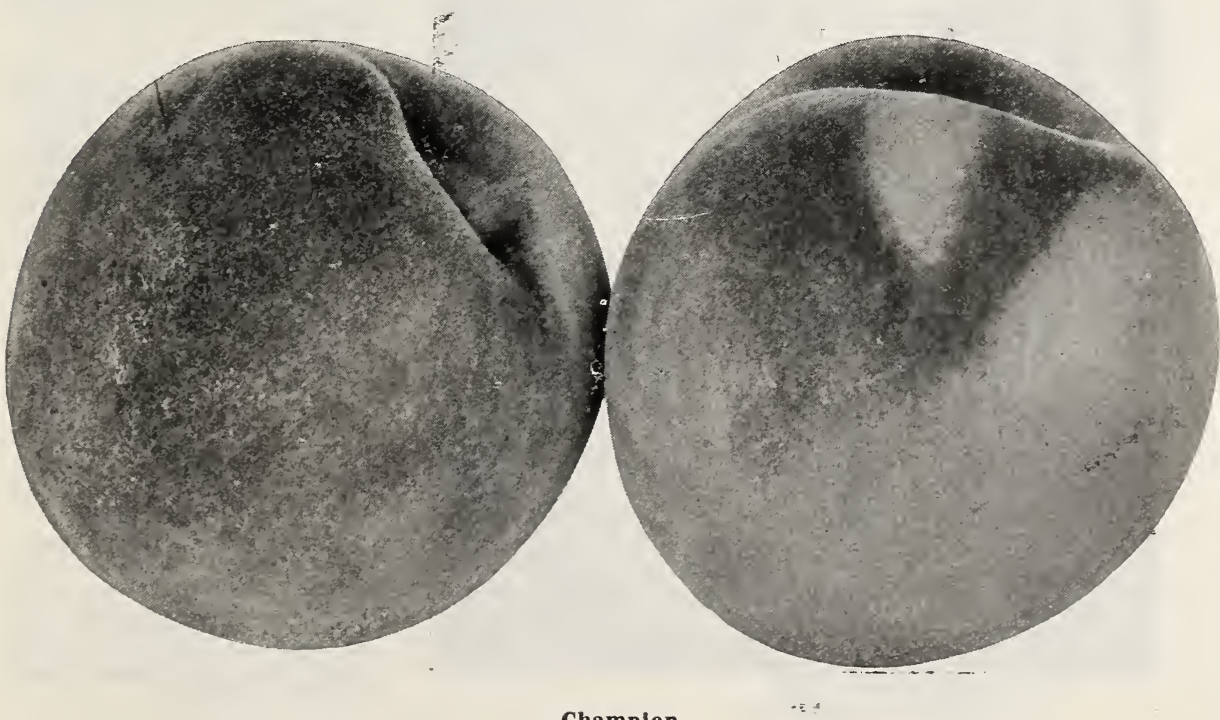


\section{Peaches-Continued}

ELBERTA (F.)-Large, yellow with red cheek. Of excellent quality; flesh yellow and melting; freestone. The market peach of America.
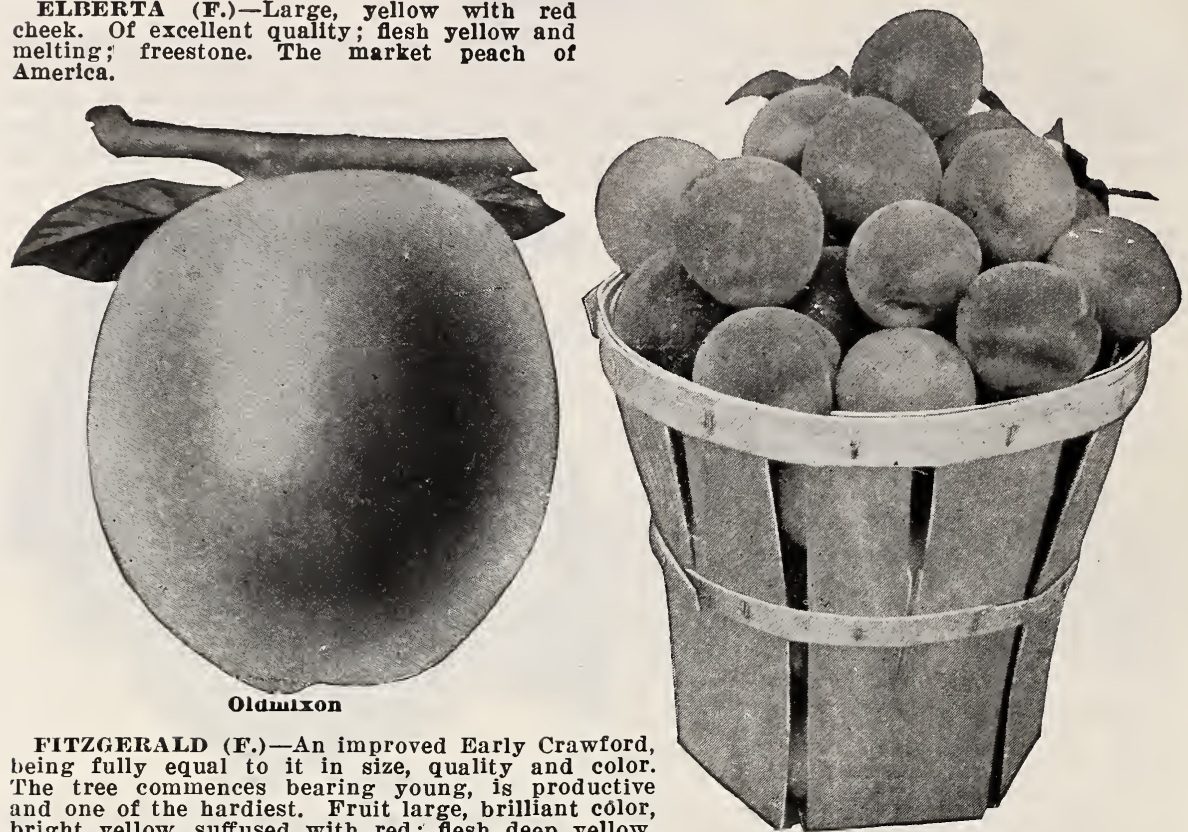

FITZGFRALD (F.)-An improved Early Crawford, being fully equal to it in size, quality and color. The tree commences bearing young, is productive and one of the hardiest. Fruit large, brilliant color, bright yellow, suffused with red; flesh deep yellow, best quality. Early September.

\section{J. H. Hale}

HEATH CLING-Large, oblong, white, slightly tinged with red in the sun. Fruit tender, rich, melting, luscious. September 15 .

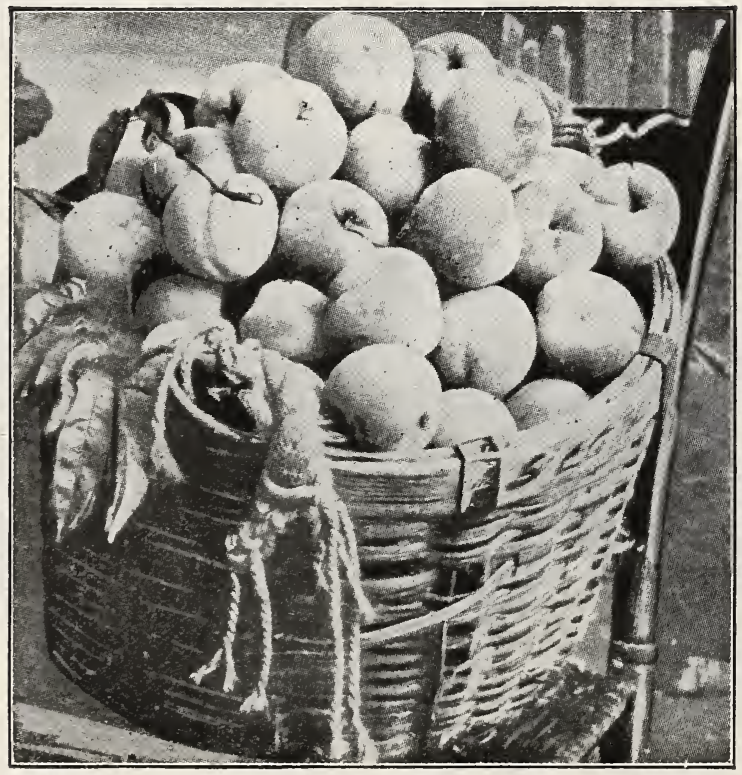

J. H. HALE-Probably no new peach has ever been introduced claiming to be so much superior in all ways. It averages one-third to onehalf larger than Elberta, ripens about five days earlier and is much superior in fla. vor. Color a beautiful golden yellow, with deep carmine blush.

OLDMIXON (C.) - One of the old standard sort. Strong, upright grower, needing heavy annual shortening. Fruit large, round, somewhat elongated. Flesh firm and of good quality. August.

SNEED (S. C.)-Fruit medium to large, greenish white blush on sunny side; juicy and good, July. Not reliable North, though desirable as a very early bearer.

TRIUMPH (F.) - Earliest yellow fleshed, with good eating and shipping qualities. Sure and abundant bearer; strong, vigorous grower. Fruit good size, yellow, with red and crimson cheek.

WONDEREUL (F.)-Originated in New Jersey. Very large, yellow with red cheek : flesh yellow, highly flavored and firm; bright red at the pit, which is small and parts freely from the flesh. Good 


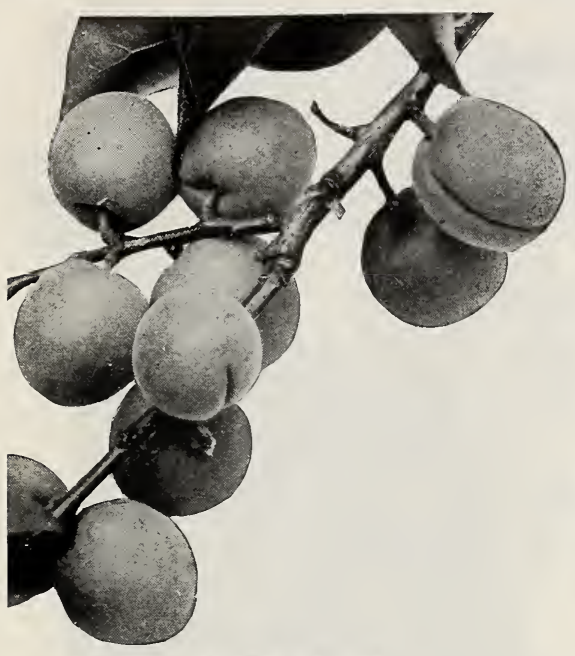

Superb Apricot

\section{Apricots}

ALEXANDER-Russian, an immense bearer. Fruit large, oblong, yellow, flecked with red; sweet and delicious.

BUDD-Russian. Large, white with red cheek; sweet and juicy; strong grower, good bearer. Late.

GIBB-Russian. Medium, yellow, sub-acid, rich and juicy, the best early sort.

MOORPARK-One of the largest and finest apricots. Yellow with red cheek. Flesh orange sweet, juicy and rich; parts from the stone. Very productive.

ROYAL-Large, roundish-oval; pale orange with faintly tinged red cheek; flesh yellow, firm, sweet, high flavored, slightly sub-acid and good quality, ripens a week earlier than Moorpark; a good market variety.

SUPERB-(Russian) - Medium, roundishoval, smooth, light salmon with numerous red or russet dots, flesh yellow, firm, subacid and good; tree hardy and productive; middle of July.

\section{Quinces}

ORANGE-Iarge, roundish ; yellow ; cooks tender and is of excellent flavor. Valuable for preserves and flavoring. Productive. September and October.

CHAMPION-Fruit large, fair and handsome. Tree bears abundantly while young. Flesh cooks as tender as an apple and without hard spots or cores; flavor delicate. The nost valuable of all.

MEECI PROIIFIC-The most profitable of all known varieties. Ripens between the Orange and the Champion. Bears early, quality good, and size large.

REA'S MAMMOTH-A very large, fine variety of the orange quince. Strong grower and productive.

\section{Mulberries}

The mulberry is not only valuable as an ornamental shade tree, but the fruit is well worthy of a place in every collection. Plant in deep, rich sandy loam. The tree requires little or no pruning and is of easy culture.

DOWNING'S EVERBEARING-This delicious variety produces a-large fruit of a dark, purplish black color ; flesh juicy, rich, sprightly, delicious. Very productive and ripening its fruit in succession for a long time. Not hardy North.

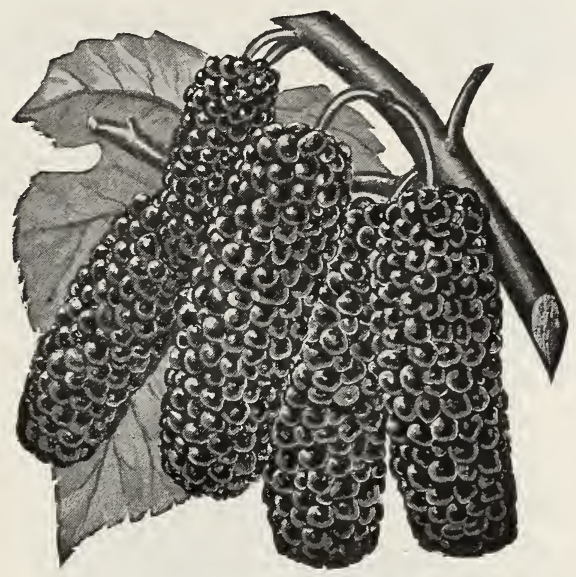

Downing's Everbearing Mulberrles

NEW AMERICAN-Largest fruit, black; delicious flavor; a very attractive lawn tree, with very large leaves. Of rapid growth. Hardy.

RUSSIAN-Good shade and ornamental tree, rapid grower, excellent wind and snow break: most valuable to supply the native birds, thus keeping them from the most precious fruits. Fruit of little value.

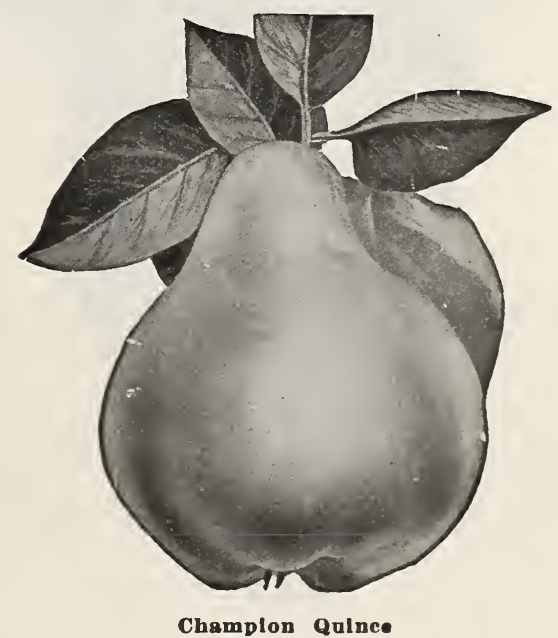




\section{Grapes}

Annual and careful pruning is essential to the production of good grapes. The roots cannot bring to maturity a fine crop of fruit if they are called upon to carry too much wood. Late in the fall is the best time to prune, when the vines are dormant.

\section{Red Varieties}

AGAWAM-Bunch large, shouldered; berry large, redlish brown, tender vinous and of excellent flavor. very vigorous and productive. Vine hardy and one of the best of its class.

IBRIGHTON-Bunch large, - shouldered; berries medium to large, round, dark red, tender, very little pulp, sweet, juicy, slightly aromatic and very good. Ripens early.

DELAWARE-The bunches are small, compact, and sometimes shouldered; berries are small with thin but firm skin; flesh juicy, very sweet and refreshing and of the best quality for both table use and for wine. Ripens with Concord or a little before: vine is liardy, productive and a moderate grower.
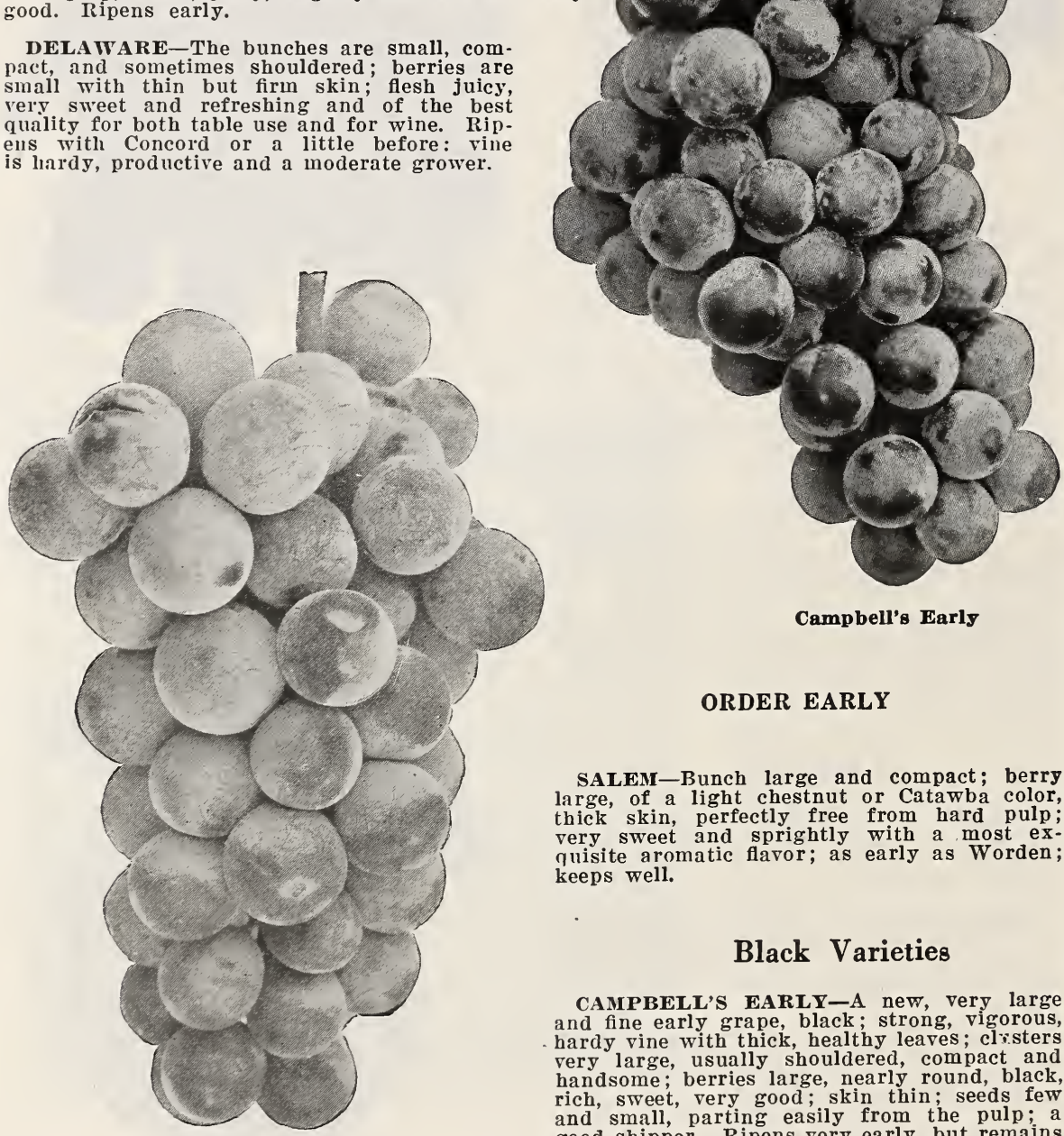

Campbell's Early

\section{ORDER EARLY}

SALEM-Bunch large and compact; berry large, of a light chestnut or Catawba color, thick skin, perfectly free from hard pulp; very sweet and sprightly with a most exquisite aromatic flavor; as early as Worden; keeps well.

\section{Black Varieties}

CAMPBELL'S EARLY-A new, very large and fine early grape, black; strong, vigorous, hardy vine with thick, healthy leaves; clisters very large, usually shouldered, compact and handsome; berries large, nearly round, black, rich, sweet, very good; skin thin; seeds few and small, parting easily from the pulp; a good shipper. Ripens very early, but remains sound on the vines for many weeks. This makes it one of the most satisfactory and profitable market sorts to grow. 


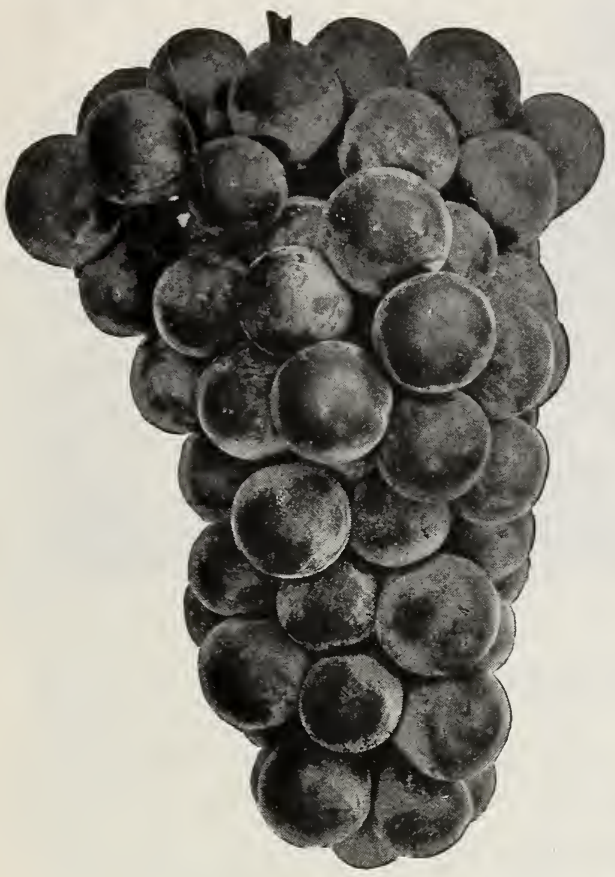

CONCORD-One of the most popular and reliable varieties we possess; bunch large, compact and shouldered; berry large, round, almost black with blue bloom, juicy, buttery and very sweet.

MOORE'S EARLY -A large grape, rip. ening a week earlier than Concord; good grower; berries large, good quality, and makes a moderate yield; very valuable as an early grape.

WORDEN-Seedling of the Concord, which it greatly resembles in appearanec and flavor, but the berries are larger. The fruit is said to be better flavored and to ripen several days earlier. These qualities will give it the foremost rank among native grapes.
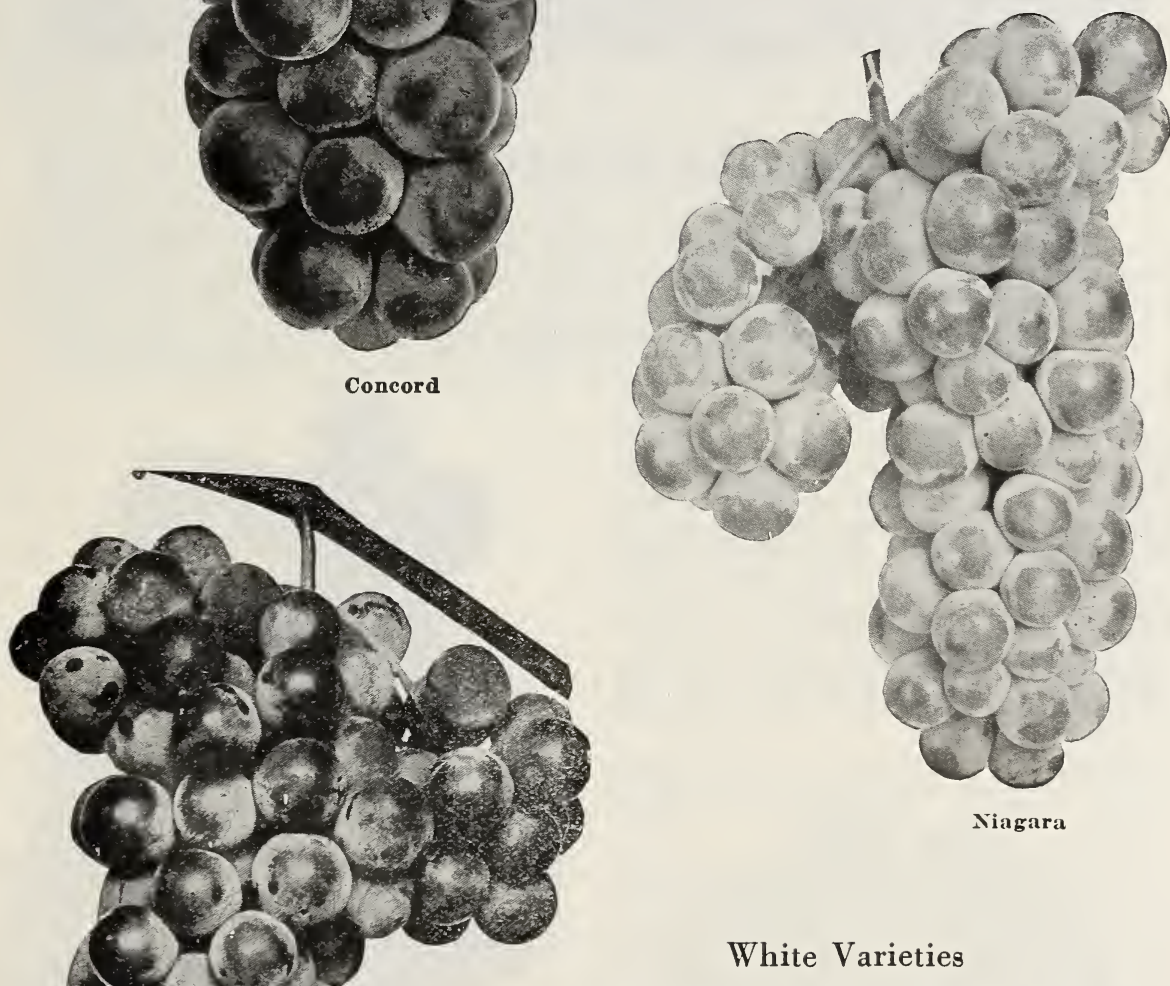

NIAGARA-Occupies the same position among the white rarieties as Concord among the black. Bunch and berries large, greenish white, changing to pale yellow when fully ripe. Skin thin but tough, quality much like the Concord.

POCKLINGTON-Seedling from the Concord. The vine is thoroughly hardy both in wood and foliage; it is a strong grower, never mildews in vine or foliage. The fruit is a light golden yellow, clear, juicy and sweet to the center, with little or no pulp; bunches very large, sometimes shoulderea; berries round, very large and thickly set. Ripens with the Concord. 


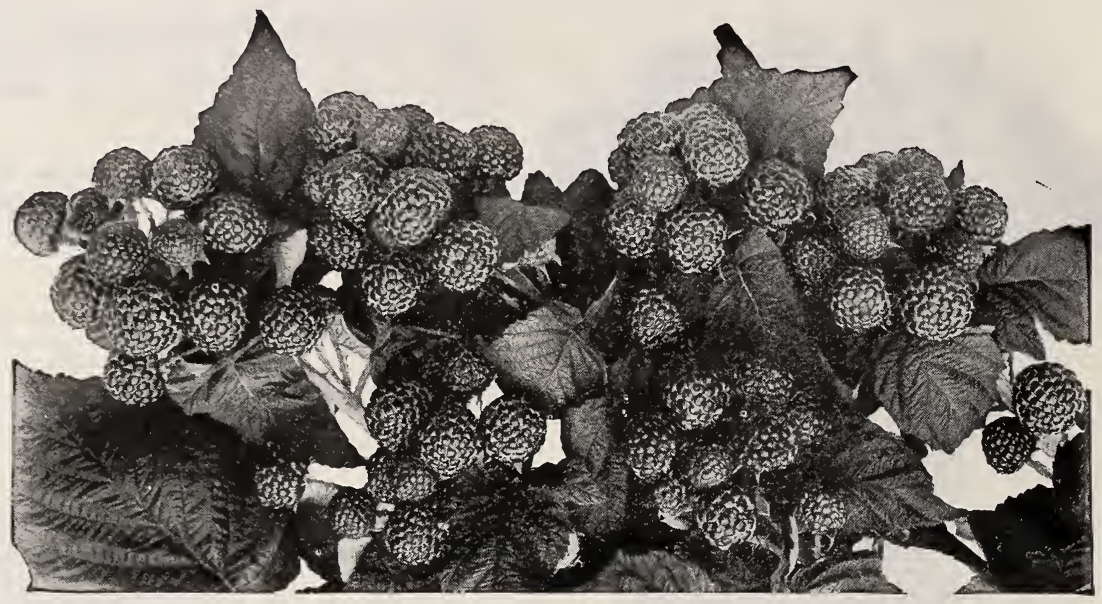

\section{Raspberries}

Plant three and a half feet apart in rows four feet apart. Thin to four or five good canes in a hill; cut out old canes as soon as through fruiting.

\section{Red and Purple Cap Varieties}

CoLumbiaN-The Columbian is a new variety of the Shaffer type, of remarkable vigor and productiveness. Not very hardy and propagates from tips. Fruit very large, often an inch in diameter, shape somewhat conical, color dark red bordered on purple; adheres firmly to the stem and will dry on the bush if not picked; seeds small and deeply imbedded in a rich juicy pulp with a distinct flavor of its own. Succeeds wherever red sorts do well and promises to become the leading variety. A most delicious table berry.

CUTHBERT-Cane tall and vigorous, berries large, conical, rich crimson and very handsome; best quality and carries well; very productive.

HAYMAKER-Purple cap. A splendid shipper and canning berry; does not crumble; excellent quality; very productive; plants vigorous and hardy.

ST, REGIS EVERBEARING - The new everbearing variety. It gives a crop of fruit all summer and autumn fruiting on the old canes in generous quantities until late in August. By this date berries begin to ripen on the young canes and continue until late in autunin. Berries are a bright crimson of large size and of surprising quality, sugary with full raspberry flavor. It succeeds upon all soils, whether light and sandy or cold heary clay and the canes are absolutely hardy.

\section{Black Varieties}

CCMBERLAND-Largest black raspberry known; unusually strong grower, perfectly hardy. The most profitable raspberry grown.

GREGG-Extra big, enormously productive. Hardy; firm black meaty berries. Late ripening and firm for shipping.

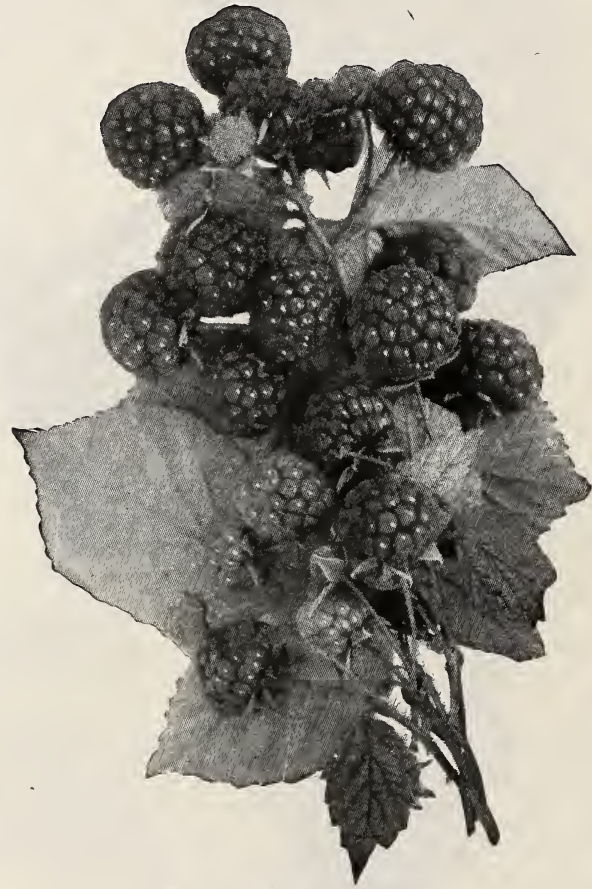

St. Regis Everbearing 


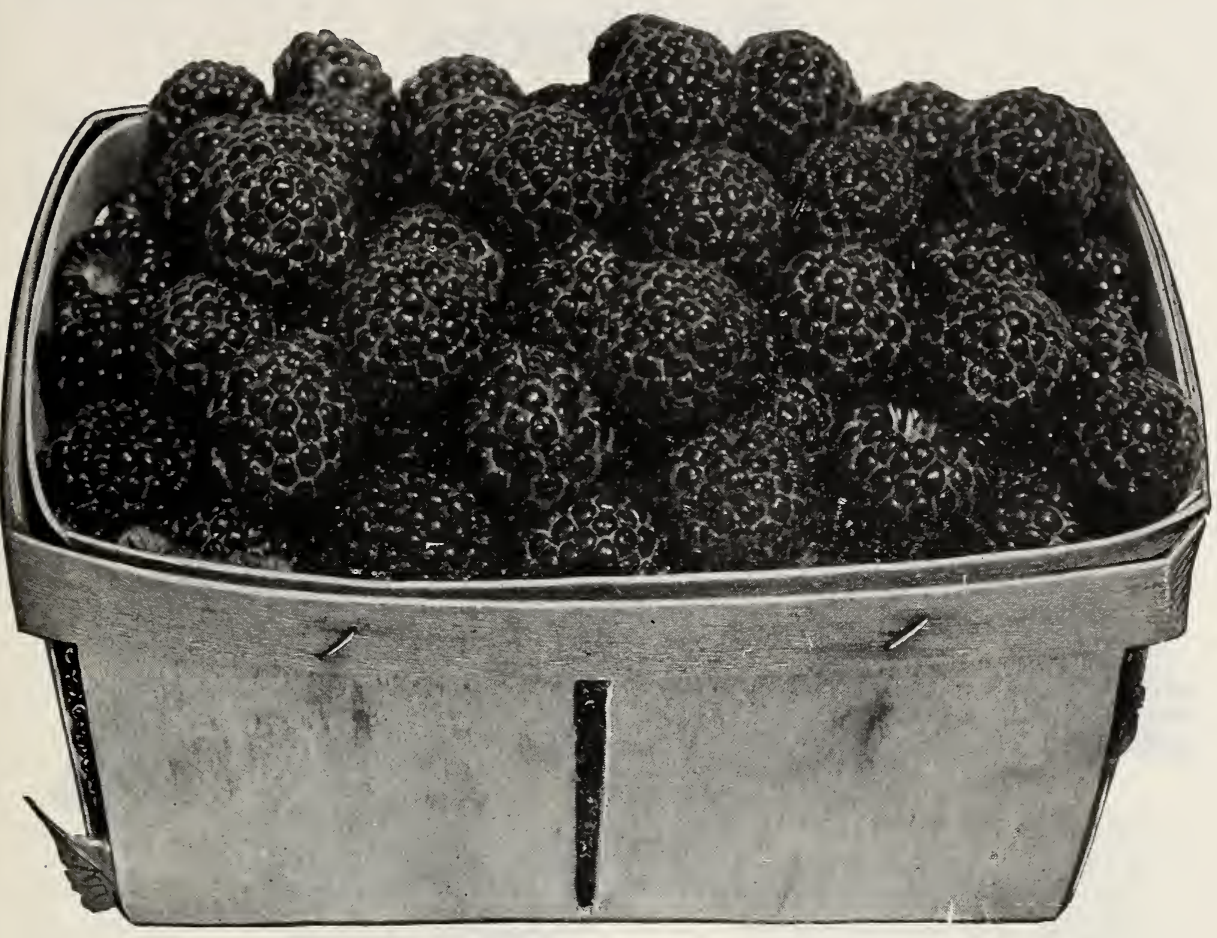

Kansas Raspberries

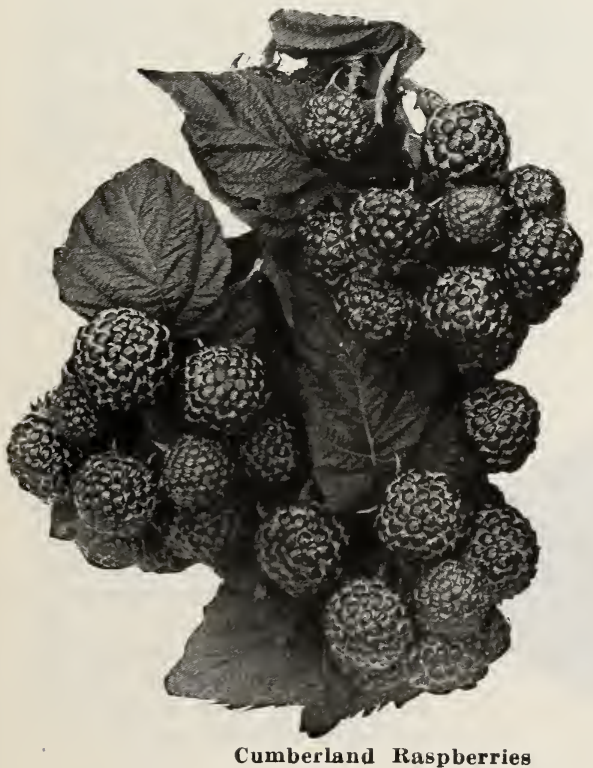

Cumberland Raspberries
KANSAS-Originated at Lawrence, Kansas. Healthy, vigorous grower; early; berry is as large as Gregg and as good a shipper. Very productive, and valuable for early market.

\section{Loganberries}

Hybrid between a blackberry and a red raspberry, originated in California. Fruit as large as a blackberry, but of deep red color. Excellent as a novelty.

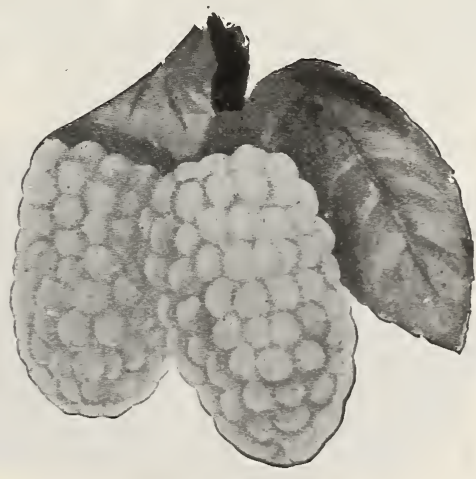

Loganberries 


\section{Blackberries}

Plant four feet apart in rows six feet apart. Pinch the canes back when four feet high. Light, moderately rich land is preferable.

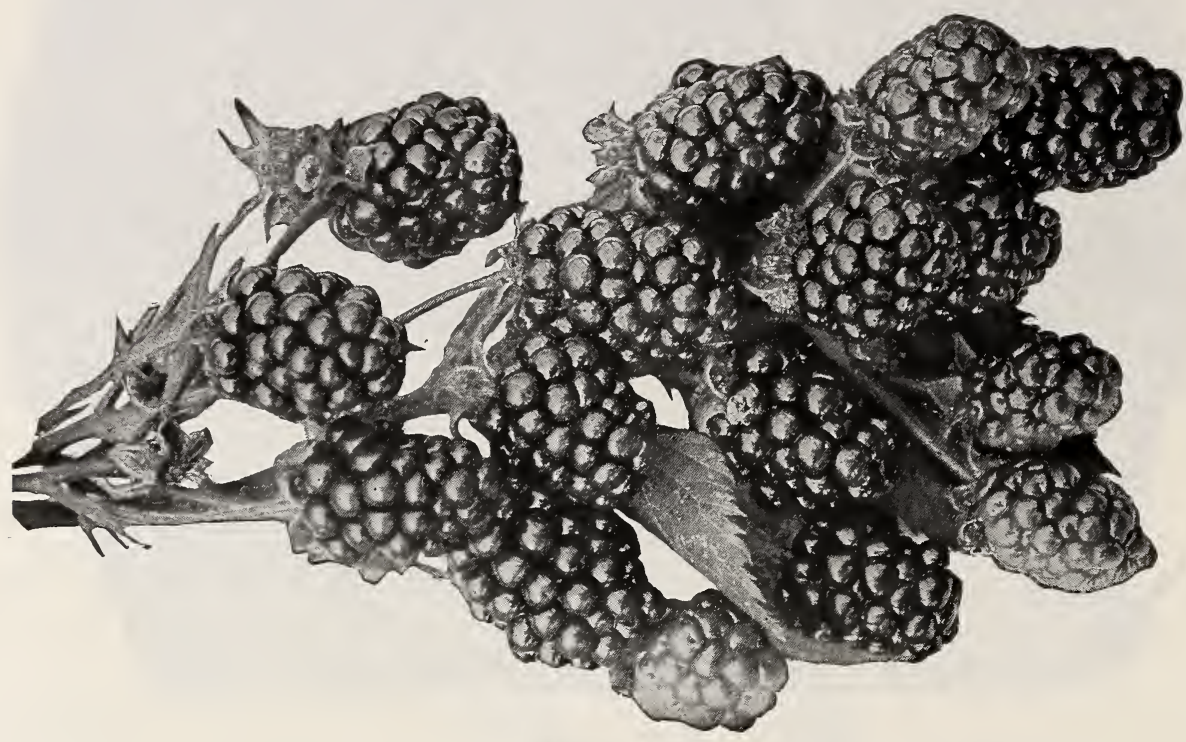

Snyder

EMIRY IIARVEST-One of the earliest, but needs winter protection north. Medium size, (quality good; prolific.

ELDORADO-A valuable blackberry for our northern climate. The berries are large, jet black, ripen well together and are borne in large clusters; they are sweet and delicious, have no hard core, and keep well after picking.

MERSEREA U-Renowned for hardiness of cane, great productiveness and large size berry. Is not "seedy" like many other sorts. Fruit jet black, and does not change color.
Berries rich, melting and luscious, with little or no core.

RATHIUN-This new blackberry has been tested over a wide area and is said to surpass any blackberry on the market. Berries large, jet black and of very fine quality. Ripens early.

SNYDER-The old standard. Very hardy, consequently much raised in cold climates. Berries medium size, juicy, rich; strong, stout cane, thrifty growth and a very broad leaf.

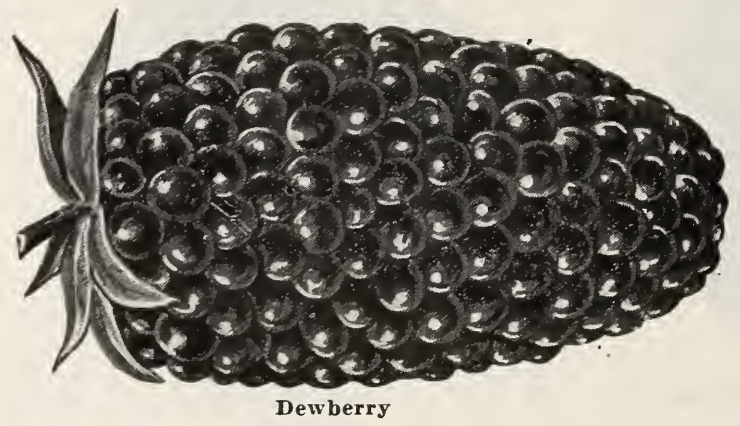

\section{Dewberries}

LUCRETIA-Fruit very large, luscious and sweet; perfectly hardy, healthy, enormously productive; a very profitable market fruit; the vines should be allowed to remain on the ground during the winter and staked up early in the spring. Fruit ripens early, is often one and one-half inches long. 


\section{Currants}

The currant is one of the most valued of the small fruits. They mature just before Raspberries and can be used either raw or cooked. Being very hardy, they do not winter-kill and are easy of cultivation, requiring little care. They can be grown in any good garden soil.

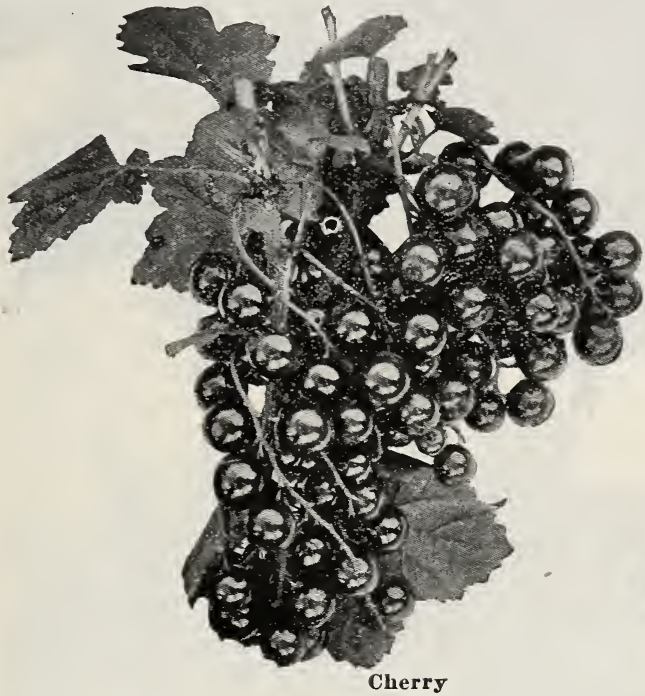

RED DUTCH-Old, well-known sort of good quality; great bearer. Fine market variety. Vigorous and upright grower.

WHITE GRAPE-Very large, yellowish white; sweet, or very mild acid; excellent for the table. The finest of the white sorts, very productive.

WILDER-Very large; bright red and attractive; a splendid sort; not so acid as most. Bush very productive; large bunches; ripens rather early, fruit keeps well.

CIERRY-The largest of all red currants; berries sometimes more than onehalf inch in diameter; bunches short; plant very vigorous and productive when grown on good soil and well cultivated.

FAY'S PROLIFIC-For size, beauty and productiveness it is a remarkable red currant. The berry is equal to cherry currant, while the flavor is superior. The stem is long, which permits rapid picking, valuable for both market and home. Fruit hangs on well, never dropping, as in other currants.

PER FECTION-Bright red, and of a size larger than the Fay; size of berries is kigintained to end of bunch. It is one of the most productive Currants. Rich, mild, sub-acid flavor and having plenty of pulp with few seeds: You can pick Perfections fast as cherries.

POMONA-This is one of the most profitable currants for the market; while not the largest in size, it outyields all other varieties. Color is a beautiful bright red, berry sweet and less acid than most of the general varieties; good size, and larger than Victoria; a vigorous grower with healthy, hardy foliage.

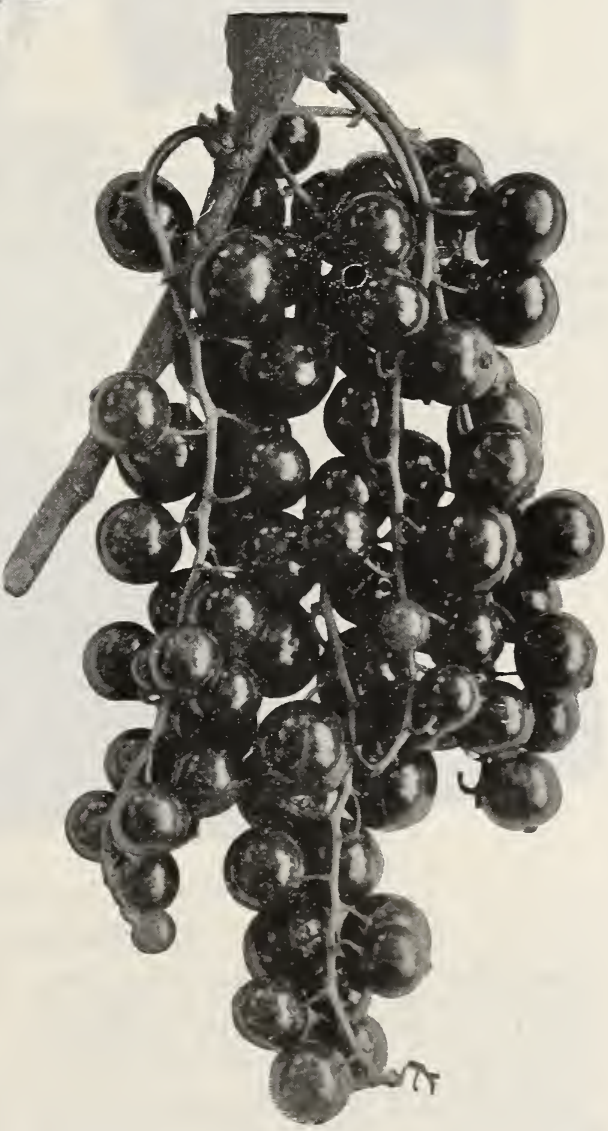

Perfection

Growers of high grade fruit trees and shrubberv. 


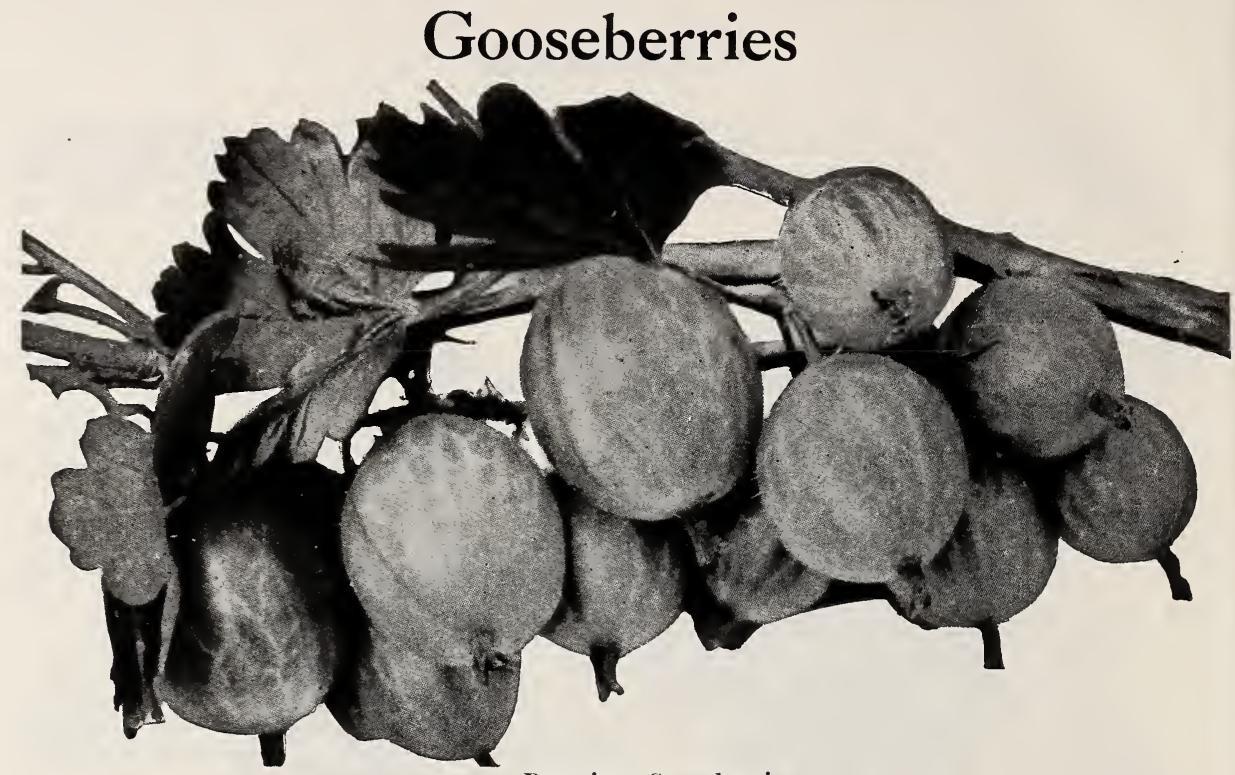

DOWNING-Fruit very large, flesh whitish green, soft, juicy and good; plant vigorous and prolific; one of the best.

IOUGHTON-The old, well-known sort ; pale red, sweet and good. It is rather small, but a productive, healthy and very reliable gooseberry.

JOSSELYN (Red Jacket) - Large size, smooth, prolific and hardy. Has been tested

by the side of all leading varieties, is freest from mildew of all. A wonderful cropper, with large, smooth, pale red fruit of first class flavor.

PEARL-A cross between Houghton and one of the large English varieties. It is very hardy and entirely free from mildew; superior in size and quality; as productive as Downing.

\section{Strawberries}

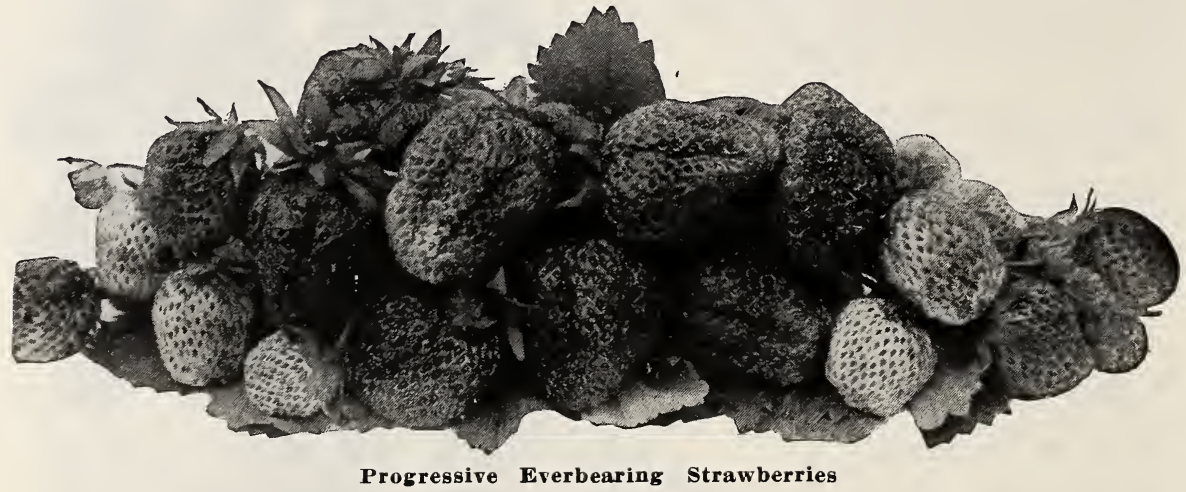

\section{Everbearing Varieties}

AMERICUS EVERBEARING (P)-Large; firm; uniform shape; bright red through and through; has native wild strawberry flavor; very productive from May until hard freezing weather. Claimed by some to be the best of everbearing strawberries.

PROGRESSIVE EVERBEARING (P)-The berries are not as large as Superb and not so good quality, but they yield well and, we think, will be one of the best known varietles of fall bearers in a few years. Fruit of Progressive is of good size, smooth, of good color and appearance.

SUPERB EVERBEARING (P)-Very large, dark red and glossy; fine quality. It begins to bear in June with immense crops and continues until late in fall. It is one of the heaviest bearers of berries in June as well as a remarkable fall bearer. Will produce a fair crop of fruit the first summer. 


\section{Spring-bearing Varieties}

AROMA (P.)-Large: dark red; uniformly roundish, heart shaped; flesh firm and of rery good quality. Stands shipping well; plants vigorous and very productive; blossoms rich in pollen and is good fertilizer for imperfect varieties. Late.

BCBACH (P)-Very prolific, excellent fiaror and large size. A number of new varieties have been pitted against it, claiming superiority in one way or another, but Bubach is among the best, and continues to grow in faror.

CHARLES I-Probably the largest and most productive strawberry grown. Quite dark red color. A rery firm fruit and for delicacy of flavor it has no equal.

DR. BURRILL (P)-Fruit is large, beautiful, dark red in color, and of excellent flaror. Shape similar to the Senator Dunlap and ripens at the same time as the Dunlap; great canning berry. It is an excellent berry for the home garden or for the market. No better.
POCOMOKE - Good variety. Hardy and productive. Berries beautiful bright red, very large and firm. Flavor good. Stands shipping well. A fine market berry.

SENATOR DUNLAP (S)-This berry is of the Warfield type, has a perfect blossom, is hardy, productive, a splendid keeper and able to hold its own under any "rough and tumble" methods of culture to which it is likely to be subjected. It is a very heavy bearer of good size, eren fruit, of a very beautiful dark red color. It is a berry to grow for either home use or market.

WARFIELD (P)-There is probably no better or more profitable berry grown for market. It is in greater demand than any other berry for canning purposes, which also creates a good market for it. Care should be taken to use the right berries as fertilizers. It needs a strong pollenizer.

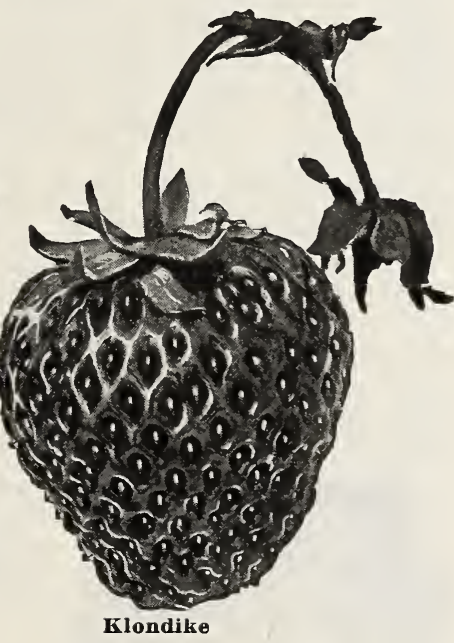

GANDY (S)-Large, light crimson: tesh of firm, good quality. Plants vigorous but should be planted in swamp or moist, clay soils. Perfect. Late.

GIBSON-This is the most popular strawberry extant today. Best for market and best for the home garden. Berry large: dark glossy, red, nearly round, very productive. Plant Gibson and success will be yours.

HAVERIAND (P)-Profitable by reason of Its productiveness and earliness; requires deep, heary soil; plant exceedingly vigorous and healthy ; fruit large, handsome and good, rather long in shape and of a bright, glossy crimson; early.

KLONDIIE (S)-Large; red; flesh firm, red to the core, with a mild and delicious flavor, unlike any other variety. Is very popular with southern growers who ship. Plant tall, compact, vigorous grower; resists frosts well and yields good crops. Perfect. Midseason.
Rhubarb

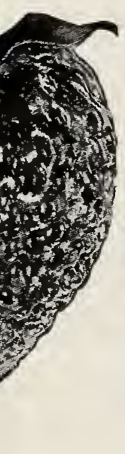

Gibson

Our business platform contains but one plank-“A Square Deal for Everyone."
This deserves to be ranked among the best early fruits in the garden. It affords the earliest material for pies and tarts, continues long in use, is valuable for canning. Use well grown roots, not divided old clumps.

WYATTS LINNEAUS-Large, early, tender and fine.

\section{Asparagus}

The first garden vegetable of spring; it is a great delicacy and comes in just when it is most needed. One hundred roots will supply a sinall family and will last for years. Set the plants about eighteen inches apart in the row. Spread the roots out in the bottom of the hole or furrow and gradually fill in as the plant grows, so that the roots will be qbout four inches deep.

CONOVER'S COLLOSAL-Best for general planting.

PALMETTO-Newer variety, earlier; probably as good. 


\section{Roses}

\section{Hybrid Perpetuals}

ALFRED COLOMB-Bright carmine red; clear color, large, deeply built form; exceedingly fine.

AMERICAN BEAUTY - The world-famous rose. Rich, rosy-crimson, exquisitely shaded. Magnificent buds. Flowers extra large and deep petaled; of beautiful form and very double. This hardy rose has the everblooming qualities of the Tea Rose with the delicious odor of the La France. The great American forcer and bedder, each shoot producing a bud. A universal favorite. Not hardy.

ANNE DE DIESBACII-Brilliant crimson, sometimes shaded with bright maroon. A superb garden sort; fragrant, one of the hardjest and best.

CLIO-A rose of perfect form and finish, with broad, thick petals, high full center, beantiful from pointed bud to fully opened fiower. The color is a delicate satiny blusl with slightly deeper center. The plant is vigurous and blooms freely, displaying its great flowers on good stems against large rich leaves.

COQUETTE DES ALPS- White tinged with pale rose, size medium, fine form, a free bloomer, dainty and attractive.

DUFFERIN-Rich, dark crimson, shading to maroon; large, full, fragrant; a good grower; one of the best dark roses.

FRAU IKARL DRUSCHKI-Snow white, very large, perfect form. A vigorous grower

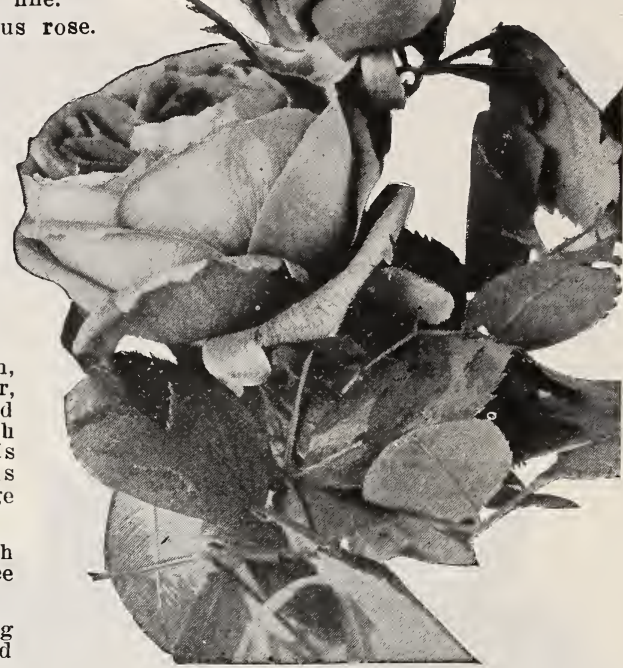

American Beauty and free bloomer. Bright, heavy foliage.

GENERAL JACQUEMINOT--This might be called the rose for the million, for it is still a unirersal favorite. Bright crimson-scarlet, exceedingly rich and velvety.

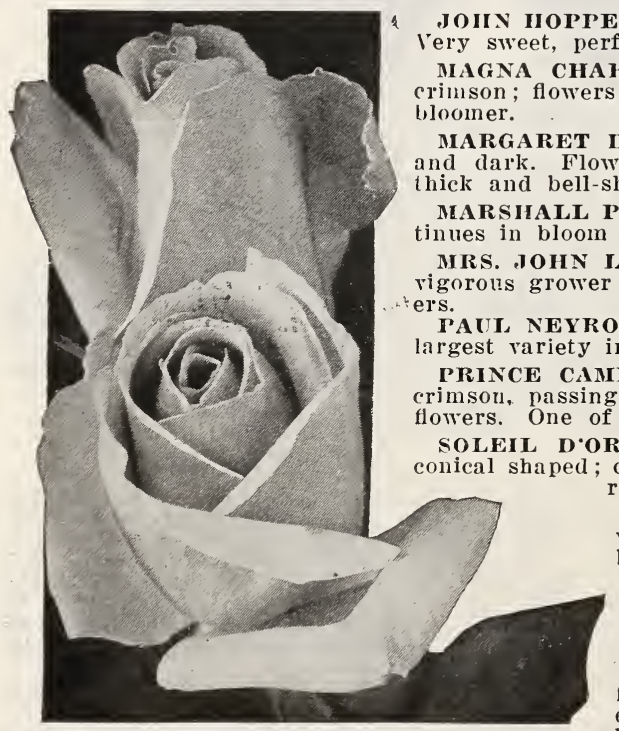

Frau Karl Druschki

PPER--Color, a brilliant pink shaded with scarlet. ery sweet, perfect, profuse bloomer.

IAGNA CHARTA-Bright, clear pink, flushed with violet rimson; flowers large, fine furm, sweet, very double and free

MARSHALL P. IVILDER-New; color cherry carmine; conin bloom long after others are out of flower.

ILAING-Deep rose; large, fine form, fragrant, grower and hardy. One of the most profuse bloom.

PAUI NEYRON-Deep rose color, good foliage: by far the variety in cultivation; one of the best. ing to intense maroon, shaded black: large full of the darkest roses and very handsome.

SOLEIL D.OR-Large, full and globular, fragrant; ouds conical shaped; color varying from gold and orange yellow to reddish gold, shaded with nasturtium red.

ULRICH BRUNNER-An upright grower with bright, healthy foliage. Flowers a re a bright cherry red, good size and of fine form.

\section{Hybrid Tea}

GRUSS AN TEPLITZ-Unquestionably the finest brilliant red, hardy, ever-blooming garden rose. The flowers are very showy and handsome. blooms constantly and continues sovered with flowers the whole season. 
KAISERIN AUGUSTA VICTORIA-IVhite. One of the most beautiful of all Roses for open-ground culture. Blooms steadily from early spring until severe frost; in fact, it is as free-blooming as any Tea Rose. Elegant, large, pointed buds and large, full-double flowers: color, delicate creamy white; deliciously fragrant.

KILLARNEY (Pink)-A phenomenal Hybrid Tea Rose, especially as to the coloring, which is an exquisite shade of deep shell-pink. The flowers are enormous, the petals frequently measuring $21 \%$ inches deep. Wonderfully strong, throwing up heavy roots crowned with long, heavy buds. Free-flowering and perfectly hardy.

\section{Climbing Roses}

CLIMBING AMERICAN BEAUTY-A strong vigorous climber but may be kept pruned back to a large size bush rose. The blooms ure the same size, color and fragrance as the old variety and when in bloom it is a perfect mass of color.

CRIMSON RAMBLER-Nothing equals this as an all round hardy garden rose, on acconnt of its brilliant color, profusion of bloom and length of time the flowers last. It may be used as a climber, or can be grown in large bush form. It blooms in large clusters of 50 to 100 flowers in a cluster, covering the foliage its entire length with a solid mass of the most beautifnl, perfectly shaped miniature crimson blossoms. Blooms last of June and remains in flower longer than any other hardy out-door rose.

DOROTIYY PERKINS-This is a splendid new shell-pink climbing rose. This new rose

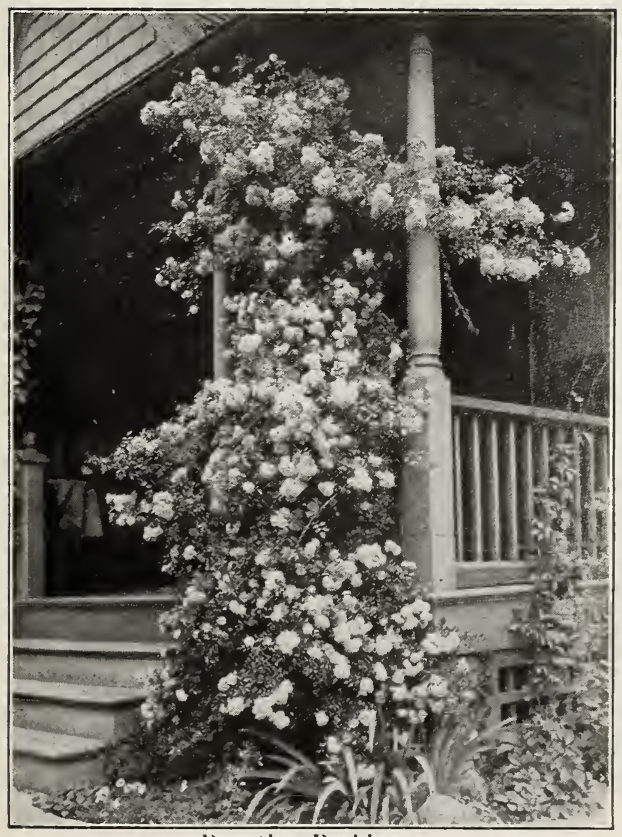

Dorothy Perkins is of the same strong habit of rrowth as the Crimson Rambler, and the flowers are borne in clusters of thirty and forty and sometimes fifty to sixty. The flowers are large for a rose of this class. Very double and sweetly scented.

EXCELSA (Red Dorothy Perkins)-This is identical with Pink and IVhite Dorothy Perkins in growth and blooming qualities. The color is a brilliant crimson, making it one of the most showy roses grown.

FLOWER OF FAIRFIELD-A sort of the well-known and famous Crimson Rambler climbing rose. 'This new rose produces it lovely flowers until killing frosts stop further growth of the plant. The flowers are pro duced in great trusses, each carrying from thirty to forty blossoms of the brightest crimson, which remains undimmed to the end.

QUEEN OF THE PRAIRIE-Bright rose in clusters, vigorous, very free bloomer.

SEVEN SISTERS-Fine, free bloomer, bright scarlet; claimed by some to be hardier than Prairie Queen.

TAUSENDSCHON-Truly called "Thousand beauties." One of the really reliable novelties. It bears its flowers in immense clusters; in color a soft pink when first opening, changing to a carmine-rose on the reverse as they expand.

WHITE RAMBLER (Thalia)-Flowers are the size of a silver quarter, perfectly filled, very fragrant; color pure white, sometimes tingerl with blush. Blooms in clusters.

YELLOW RAMBLER (Aglaia)-Flowers medium size, cun-shaped, nearly full, sweet scented; blooms in large clusters; color very light yellow. Of the class and habit of the famous Crimson Rambler.

\section{Miscellaneous Hardy Roses}

MADAM PLANTIER - Flowers pure white of medium size; full; somewhat rosy in the bud form; produced in greatest abundance quite early in the season. The leaves are small; the bush hardy and spreading. Fine for masses, hedges, borders, cemeteries, etc.

PERSIAN YELLOW-Similar to above, but with flowers fuller and of better form. Bright yellow; the most double of this class. The finest hardy yellow rose.

\section{Baby Rambler Roses}

PINK BABY RAMBLER-A brilliant rose color.

RED BABY RAMBLER-Crimson flow ers. Very attractive and popular.

WHITE BABY RAMBLER-Pure white flowers, produced in large candelabrashaped trusses.

\section{Moss Roses}

BLANCHE MOREAU-Pure white, large and full, perfect form and well furnished with deep green moss. Very strong grower.

CRESTED MOSS-The deep pink buds are surrounded with a mossy fringe and crest; fragrant. One of the best.

PERPETUAL IVHTE - Pure white, blooms in clusters, double, beautiful, vigorous.

SALET-Clear rose color, very double, of vigarous growth and abundant bloom. Perpetual. 


\section{Ornamental Shrubs}

The planting of ornamental shrubs is very largely on the increase, and this is as it should be, for with a good selection the lawn can always be beautiful. They are mostly of medium size, enabling one to plant a great variety on a small plat, and the wonderful assortment of foliage from the darkest green and purple to light orange and silver tints. This addition to the great variety in the blossonis, all unite to keep up a never failing interest. We have selected the very best for our climate.

FLOWERING SHRUBS - Variegated Colored Foliage-Rarberry, Golden Elder, Syringa, Variegated Weigela.

Shrubs that Flower in May-Flowering Almonds, IIoneysuckle, Japan Quince, Lilac, Snowballs, Spireas, Wistaria.

In June-Clematis, Deutzia, Elder, Honeysuckle, l'aeonies, Lilacs, Snowball, Spireas, Syringa, IV eigela, Wistaria.

In July-Clematis, Spirea, Honeysuckle.

In August and September-Bignonia, Clematis, IIoneysuckle, Hydrangea.

ALTHEA, or ROSE OF SHARON-Valuable liecause they bloom so profusely in late summer when other flowers are scarce. They form beautiful groups of hedges, their variety of colors making it possible to use quantities of them eren in small grounds.

ALMOND, FLOWERING-Pink and white varieties. These beautiful shrubs are desirable and scarce. Hardy.

CA LYCA NTHUS (Carolina Allspice)-A well known native bush very double, purple fragrant flowers.

CORNUS SIBERICA (Dogwood)-Grows 5 to 10 feet high, with clusters of fine, white flowers, succeeded by a fall crop of ornamental berries. Branches turn to blood-red during winter.

CORNUS STOLONIFERA (Red osier Dogwood)-A rather dwarf form of the Dogwood. Bark red, flowers white, followed by pure white berries.

DEUTZIA (Pride of Rochester)-A very desirable shrub, of strong, hardy growth, bearing an abundance of beautiful racemes of purplish-white towers.

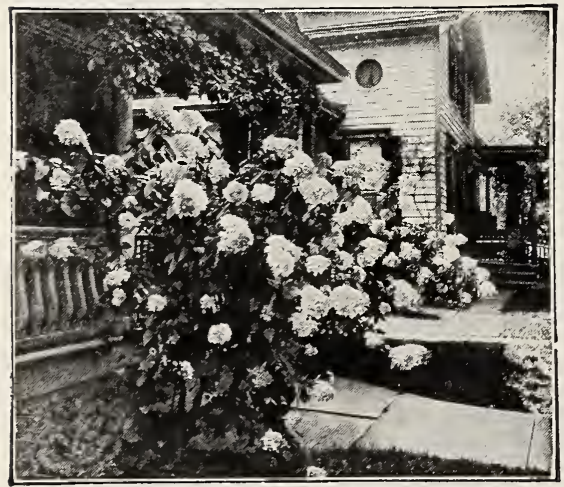

Iydrangea, P. G.

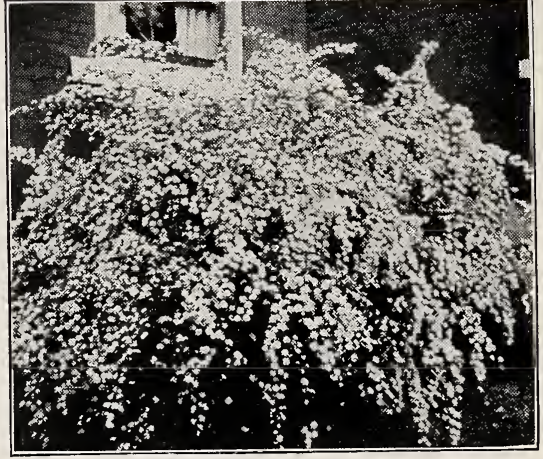

Spirea Van Houtei

ELDER GOLDEN-The leaves are a bright and constant golden color; the flower cluster pure white. Valuable for contrasts and for massing.

FORSYTHIA - GOLDEN BELL - Pretty shrubs of medium size, blooming in spring before the leaves appear. Flowers are yellow, drooping, and are borne along the stem. They are exceptionally hardy and thrive in any locality. The green branches also add to their attractiveness and the graceful bush or pendulous habit.

HONEYSUCKLE, UPRIGHT (White or Pink)-White or pink flowers which contrast beautifully with the foliage. Blossoms in June.

HYDRANGEA, ARBORESCENS STERELIS (also Hills of Snow, Summer Hydrangea, ol Snowball Hydrangea.) The blooms are of the very largest size, of pure snow-white color, and the foliage is finely finished. One of its most valuable characteristics is its coming into bloom just after the passing of all the early spring shrubs.

IIYDRANGEA, PANICULATA GRANIDIFLORA-These plants are absolutely hardy, grow in any soil and bloom the same year they are set out. They flower abundantly, hearing hundreds of immense panicles of bloom. White turning to rose in autumn. An annual shortening of branches tends to increase the size of the flowers. Very tine and valuable for cemetery planting.

LILAC (Common Purple)-Bluish purple nowers, well known.

LILAC (Common White)-Cream white flowers.

IILAC (Persian Purple) - of more slender growth and finer follage than the common lilac. Flowers purple in large, loose panicles. 
PYRUS JAPONICA (Japan Oulnce)-The most beautiful of early blooming shrubs, and as a mass of scarlet or crimson, tinged in the exquisite green of its glossy foliage, it has no rival.

SNOWBALL (Common)-A popular shrub, Makes a large bush. Bears balls of pure white flowers in June.

SPIREAS-Decidedly the best and hardiest family of shrubs for the Northwest. Many beautiful varieties of different colors and times of flowering, from May to September. Of easiest culture; should be planted every where.

SPIREA, ANTHONY WATERER-A small dwarf variety $11 / \mathrm{ft}$., covered with flat heads of pink nowers. Used for edging and in front of slirubbery.
SPIREA, VAN HOUTTEI-Graceful, with long, drooping sprays, thickly studded with handsome, pure white flowers; hence its popular name, "Bridal Wreath." The finest Spirea of them all.

SYRINGA (Mock Orange)-Beautiful, tall, vigorous, hardy, with profuse, white, orangelike flowers in May. Very popular.

WEEIGELA ROSEA-Hardy, with profuse, rosy, trumpet shaped flowers in May. The most superb shrub of the season.

WEIGELA, CANDIDA-Flowers pure white, produced in June and continue to bloom nearly all summer.

WEIGELA, EVA RATHKE-Flowers a brilliant crimson; a beautiful, clear, distinct shade.

WEIGELA, VARIEGATED LEAF-Of dwarf hatit and clearly defined silvery variegated leaves; flowers rose colored.

\section{Hardy Climbing Vines}

Ornamentals of this class are so hardy and so beautiful that they deserve groater attention than they receive. No artist can produce pictures equal to the wealth of beauty displayed by the elegant Wistaria, the graceful Honeysuckle, or the charming and magnificent Clematis when in the glory of full bloom.

AMPELOPSIS (American Iry or Virginia Creeper, also called Woodbine) $-A$ very rapid grower, having beautiful dark green foliage, assumes rich crimson hues in a utumn.

AMPELOPSIS (Veitchil or Boston Iry)Leaves a little smaller and more ivy like in form than the foregoing. Overlapping each

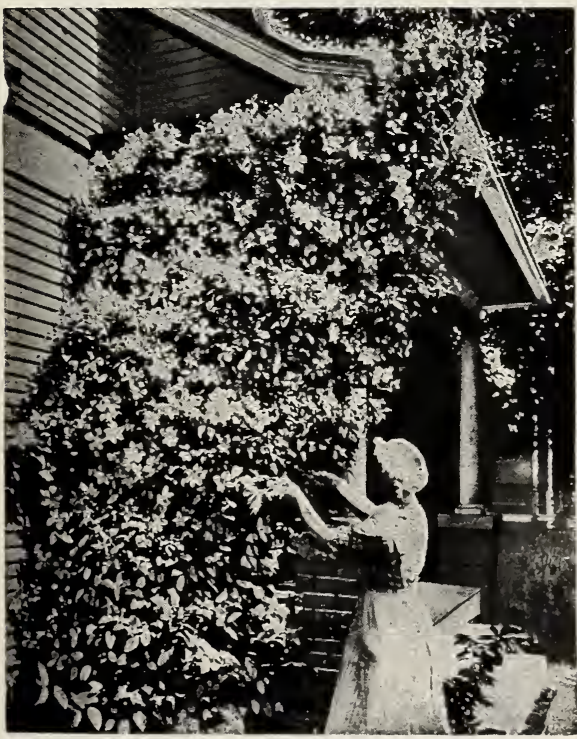

Clematis, Jackmanil other they form a dense sheet of green. The plant requires a little protection the first winter until it is established.

ARISTOLochia (Dutchman's Pipe)-A native species of climbing habit and rapid rrowth, light green foliage, and pipe-shaped yellowish brown flowers.

BIGNONIA (Scarlet Trumpet Flower)A splendid climber, vigorous and hardy with clusters of large trumpet-shaped scarlet flowers in August.

CLEMATIS-The different varieties and species of Clematis now in cultivation are of the highest beauty and utility. They vary greatly in their foliage and flowers and are adapted to various uses.

CLEMATIS, JACKMANII-A very profuse blooming variety with flowers from four to six inches in diameter, of an intense violet-purple color borne successionally in continuous masses on the summer shoots. The very best sort for general planting.

CLEMATIS, HENRYII-Fine bloomer: flowers large, of a beautiful creamy white, consisting generally of from six to elght sepals. June to October.

CLEMATIS MADAME EDOUARD ANI) RE-Flowers large, of a beautiful bright relvety red, very free flowering and continuous bloomer.

CLEMATIS PANICULATA-A great novelty. One of the most desirable, useful and beautiful of hardy garden vines, a luxuriant grower, profuse bloomer with fine foliage. Flowers of medium size, very pretty and fragrant, produced in the greatest profusion in late summer.

HONEYSCCKLE (Monthly Fragrant)Blooms all summer; very sweet. 


\section{Hardy Climbing Vines-Continued}

HONEYSUCKLE (Hall's Japan)-A strong, vigorous, evergreen variety with pure white flowers changing to yellow Very fragrant; covered with flowers from June to November. Better have some winter protection.

IONEYSUCKLE SCARLET TRUMPETOne of the handsomest in cultivation; strong, rapid grower; flowers a bright scarlet, not much odor.

IVISTARIA (Purple) - A most beautiful climber of rapid growth, producing long, pendulous clusters of pale blue flowers. When well established makes an enormous growth. It is very hardy and one of the most superb vines ever introduced.

\section{Hardy Herbaceous Perennials}

DAIILIAS- Well known autumn flowering plants, growing from two to five feet high, and producing a profusion of flowers of the most perfect and beautiful form, varying in color from the purest white to the darkest inaroon.

GLADIOLI-Of all our summer flowering bulbs gladioli stand at the head of the most varied and beautiful class. The flowers are produced in spikes two feet in height and upwards; the brilliant scarlet and crimson of some form a striking contrast with the delicate shades and penciling of the lighter colored varieties. By planting at intervals from May 1st to middle of June a succession of flowers can be had from July to October.

GOLDEN GLOW-IVe call attention to this notable uovelty, and offer it as the finest herbaceous border plant introduced for many years. It is of easy growth and is giving complete satisfaction. But few plants can vie with it in attractireness. There is no floral novelty before the public to be compared to it for effectiveness and worth.

PEONIES-No flowers exceed the Peonies in popularity, and none are more easily grown. They are seldom attacked by insects or disease, and are perfectly hardy, requiring no covering in the severest weather. They thrive in all kind of soil and flourish in a rich deep loam.

No hardy perennial is of more permanent value than the Peony. The first cost is the only cost, and they continue to increase in size and value for many years. The foliage is rich and beautiful deep green color, which reuders the plant very ornamental even when out of flower, and no other flowers are so well adapted for interior decoration and none make more massive color effect when planted in a border or in a bed on the lawn. Their popularity has increased during the past few vears since the new improved varieties have been disseminated. Peonies range in color from cream and pure white through the various shades of pink and red to the deepest purple and maroon, in all possible combinations of tint and form.

\section{A List of Good Named Varieties}

Festiva Maxima-Very large, pure white flowers, with some blood-red stains in center ; tall stalks; beautiful foliage and very free-flowering. In every respect one of the most desirable white Peonies in cultivation.

Edulis Superba-Beautiful. brilliant rosepink, large well formed, full flower on strong stem. Blooms very early, just

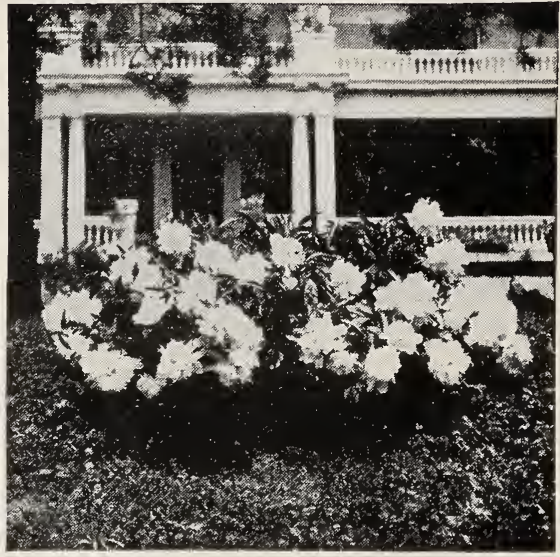

Peonies

before Festiva Maxima. Lasts well. Fragrant and good in every wáy.

Felix Crousse-Large, compact. Deep rosered. Fragrant. Strong, robust grower. Free bloomer.

PERENNIAL PHLOX (Strong Field Grown Stock.

$A$ choice list of varieties-

Bridesmaid, white with large crimson center.

Fantome, deep lavender, edged and shaded with white, dwarf.

Fraulein G. Von Lassburg, pure white, immense panicles.

Isabey, Salmon-pink.

Lothair, bright crimson.

Pecheur d' Island, lavender-cerise.

Rynstrom, a lively shade of rose-pink, very large.

Sunset, dark, rosy-pink.

YUCCA FILAMENTOSA (Adam's Needle)Thread-leaved creamy white: stem three to four feet high, covered with bell-shaped flower, on laterals forming a pyramid; very striking. 


\section{Flowering Bulbs for Fall Planting}

CROCUS-In various colors, single and double.

HYACINTHS-Among the bulbs used for winter fowers, Hyacinth stands foremost 01 . the list. Two methods are employed in flow ering the hyacinth in winter, one in glasses filled with water, the other in pots or boxes of soil.

JONQUILS-Pretty varieties of the Narcissus, have a very agreeable fragrance; adapted to either pots or out-door culture. The bulbs being small six or eight may be put in a six-inch pot.

LILIES-The lilies are entirely hardy with few exceptions. Quite fragrant and most of the varieties are very beautiful.

LILIUM AURATUM-Gold banded lily of Japan.

L. CANDIDUM-Common white.

L. HARRISH (Bermuda Easter Lily)-Pure white, trumpet shaped flowers, very fragrant. The finest lily grown.

L. LANCIFOLUM ROSEUM (Rose Spotted).

L. LANCIFOLUM RUBRUM (Red Spotted).

L. TIGRINUM (Double Tiger Lily)-Bright orange scarlet with dark spots.

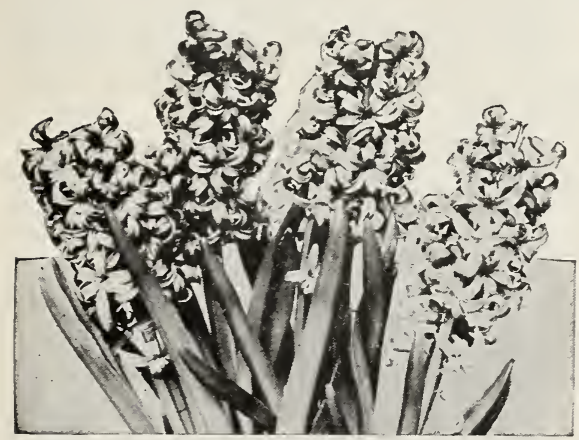

Hyacinths

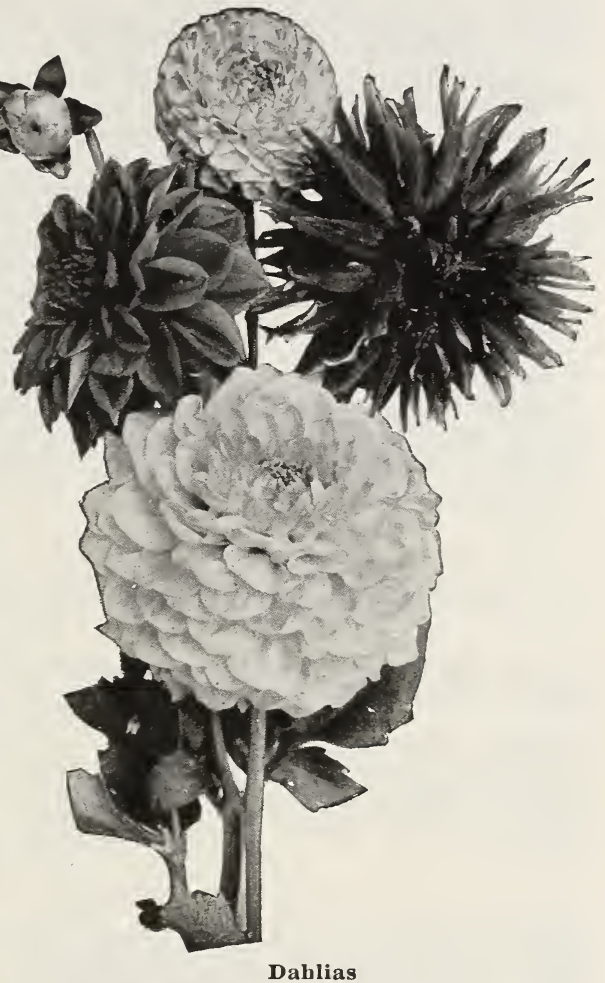

LIUY OF THE VALLEY-This lily is as hardy as any plant can possibly be, and when planted in open ground will increase pretty rapidly.

TULIPS-Owing to the late spring frosts bedding plants cannot safely be planted before the early spring flowering bulbs are thorough blooming. They thrive well in almost any soil. Should be planted during October and November.

\section{Hedge Plants}

BARBERRY (B. Thunbergii) - A low, spreading bush, with small branches corered with small sharp thorns and in spring with small yellow flowers, succeeded by bright scarlet berries; foliage changes in the autumn to shades of scarlet and gold: makes a dense, thick hedge.

PRIVET (Amoor River North) - This is the inost beautiful hedge plant grown. It has a luxuriant, glossy leafage and thick clusters of fragrant white flowers. Hardy, free-growing, of dense. neat habit, attractive all the year, in berry leaf, or flower. Makes a beautiful specimen plant, a fine screen, group or hedre.

PRIVET (California)-One of the finest for hedges where it does not winter-kill. The foliage is large and glossy, and is almost evergreen. While we can furnish the California Privet for hedging purposes, we do not recommend it as being absolutely hardy north of the $41 \mathrm{st}$ parallel of latitude. 


\section{Hardy Ornamental Trees}

The stock of ornamental trees that we offer will be found to comprise a sufficient number of kinds that are really valuable, so that our customers may, from the list offered, secure such a variety as will give full satisfaction. Poplar.

For Streets, Roads and Wide Avenues-American Elm, Sugar and Silver Maple, Carolina Linden.

Single Specimens of Large Growth to be Branched from the Ground-Birches, particularly Cut-Leaf Weeping; Austrian and Scotch Pines, Norway and Colorado Spruces, Balsam Fir.

Single Specimens of Medium Growth to be Branched from the Ground-Prunus Pisardil, Hemlocks, White Pine, Arbor Vitae.

Strong Growing Trees of Pyramidal IIabit-Carolina Poplar, Balsam Fire, Pyramidalis Arbor Vitae.

Trees that Thrive In Moist Locations-American Elm, American Linden, Ash, Catalpas, Poplars and Willows.

Trees that Thrive on Dry Knolls or Poor Solls-Silver Leaf Maples and Poplars.

Best Trees for Windbreaks-Norway and White Spruces, Scotch and White Pine, Carolina Poplars and Silver Maples.

Flowering Trees-Judas Tree, Fringe Tree, White and Purple Iindens, Ilorse Chestnut, Catalpas.

Cut-Leaf Trees-Cut-Leaf Weeping Birch, Weirs Cut-Leaf Maple.

Purple and Scarlet-Leaved Trees-Purple-Leaf Beech, Plum, Purple Norway Maple.

ASH WHITE-Rapid growing tree, of fine, symmetrical outline. A valuable street or park tree and should be extensively planted.

BIRCH, WHITE-A beautiful native tree particularly in the northern part of the country. Its shining white bark and slender, dark brown branches make it a conspicuous and very attractive object. Foliage large and handsome.

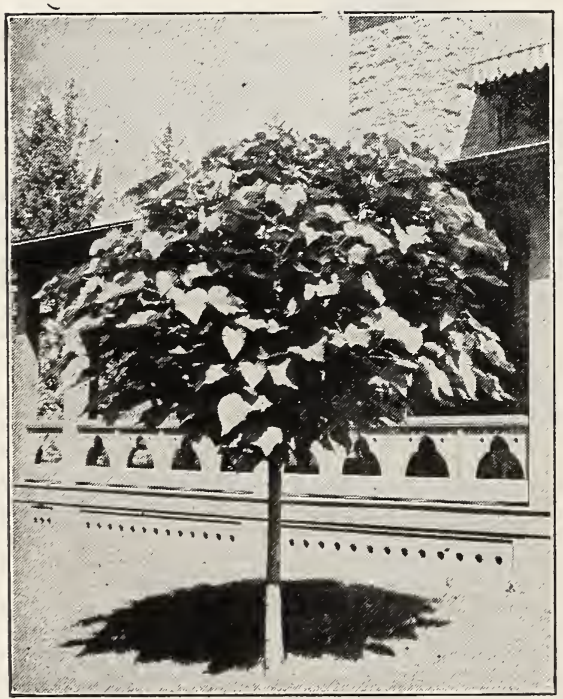

Catalpa Bungei
BLACK OR YELLOW LOCUST-A native tree of large size, rapid growth and valuable for timber as well as ornamental; flowers are white or yellowish, very fragrant and appear in June.

BOX ELDER (Maple Ash Leaf)-A fine, rapid growing tree, with handsome, light green, pinated foliage and spreading head; very hardy.

CAROLINA POPLAR-Takes front rank among best of poplars; it is one of the most rapid growers among shade trees. Its branches spread just enough to give it a symmetrical appearance. It has advantages over other shade trees because it will grow on any kind of soil, swampy or muck, light or heavy. Its roots penetrate the hardest soil, it withstands all hardships and thrives in places where others fail to live. It is easily started and gives shade in a short time. Its leaves are large and stay green till quite late in the fall.

CATALPA BUNGEI-A remarkable species forming a dense, round umbrella-like head; makes a beautiful lawn tree when grafted or budded on a high stem.

CATALPA SPECIOSA-A variety which is said to have originated in the West; it is very hardy and a rapid grower and is being extensively planted for commercial purposes; has broad deep green leaves and beautiful large blossoms, making it a highly ornamental tree for lawn or street. Valuable for planting in groves for growing poles, posts and railroad ties.

CHESTNUT, AMERICAN SWEET - Well known beautifil tree, valuable for fruit and timber. Should be planted only on thill, dry soils.

CRA B (Bechtel's Double Flowering)-This blooms in early spring exhaling a most delightful fragrance from its masses of double, delicate pink flowers. 
ELM, AMERICAN WHITE-The noble, spreading, drooping tree of our woods. One of the grandest of park or shade trees.

EUROPEAN LINDEN-A medium size tree with rather small dark green leaves, compact and conical. It blooms profusely, and the sweet odor is carried over a whole lawn. Unsurpassed for formal or avenue planting.

FRINGE, PURPLE-Very conspicuous in mid-summer when reiled with a thick mist of dusky purple flowers, so light as to simulate wreaths of smoke. This is sometimes called "Smoke Tree."

HACKBERRY Or NETTLE TREE - A highly ornamental tree, somewhat similar to the elm but more formal. The ripe fruit is a joy to boys and birds in the fall and early winter. Used somewhat as a street tree, but not half appreciated.

HONEY LOCUST-A rapid-growing native tree with powerful spines and delicate foliage; the greenish flowers appearing in early summer are followed by flat pods 8 to 10 inches long; used extensively for hedges.

HORSE CHESTNUT-Common or white, flowering. A very beautiful, well known tree, with round, dense head, dark green foliage, and an abundance of showy flowers in early spring.

LINDEN (American or Lime)-A rapid growing, large, beautiful native tree. Flowers very fragrant.

MAPLE (Silver Leared)-Leaves white underneath; of rapid growth; very ornamental and one of the best street trees we have.

MOUNTAIN ASH EUROPEAN-A fine tree with dense and regular head; covered from mid-summer to winter with great clusters of bright scarlet berries.

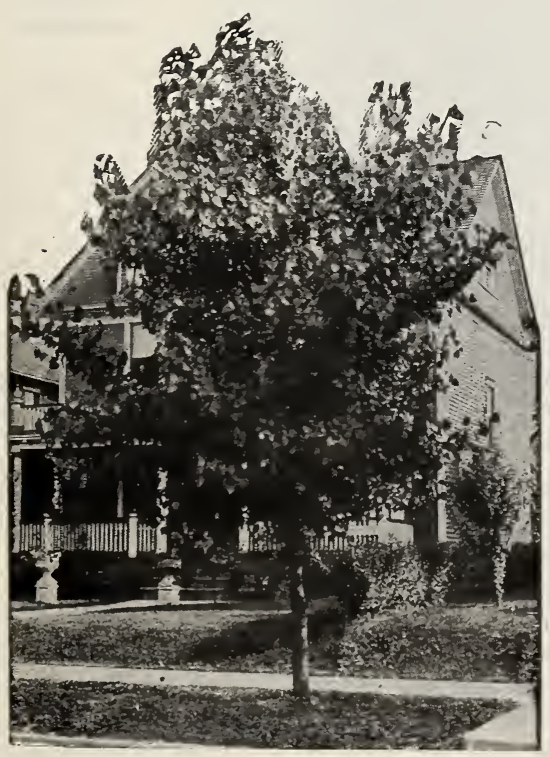

Carolina Poplar

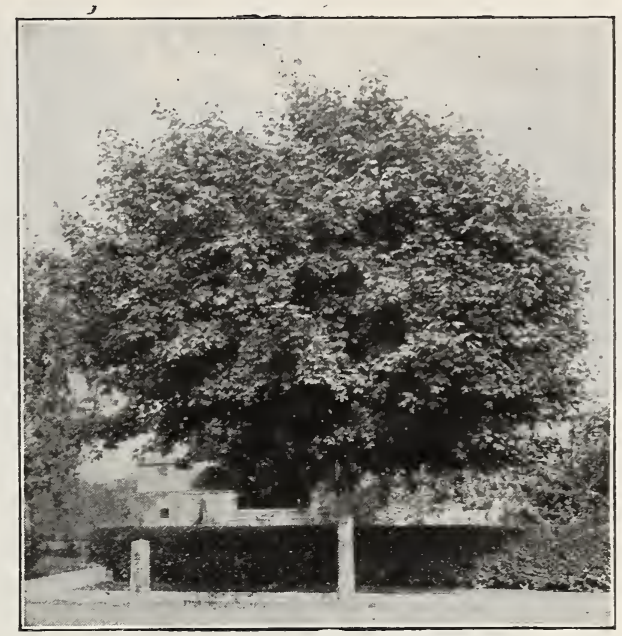

Norway Maple

NORWAY MAPLE-Of spreading rounded form; foliage large, dark green; $a$ rich and majestic shade tree.

SUGAR MAPLE-A beautiful, stately tree of fine form; a desirable shade tree. Slow grower.

SYCAMORE AMERICAN OO PLANE TREE -A well-kuowu tree, verv common throughout the Uniter States; leaves heart-shaped at base, the short lobes sharp pointed; branches are wide spreading.

SYCAMORE ORIENTAL PLANE Or EUROPEAN (P. Orientalis)-A rapid growing, erect tree with bright green foliage; much more esteemed than the American variety as a shade tree; very desirable for parks, streets and lawns.

WALNUT, BLACK-Valuable for nuts and timber. It is hardy and succeeds best on a rich, deep, moist soil. Too well known for long description.

\section{Weeping Varieties}

BIRCH (Cut-Leaf Weeping)-Erect, stately, rapid growing tree, with long, slender, pendant branches, delicately cut leaves and silvery white trunk; especially fine when near evergreens; hardy; the most elegant weeping tree on the list.

ELM CAMPERDOWN, WEEPING-A VIgorous grower; leaves large, dark green and glossy, covering the tree with a luxuriant mass of verdure; very desirable as an ornamental.

MOUNTAIN ASH (European Weeping)-A strong grower; remarkably pendant; perfectly hardy; succeeds admirably on prairle soil.

TEAS' WEEPING MULBERRY-Forms a perfect umbrella shaped head, with long slender branches drooping to the ground, parallel to the stem; very hardy; one of the prettiest small weeping trees. 


\section{Hardy Evergreens}

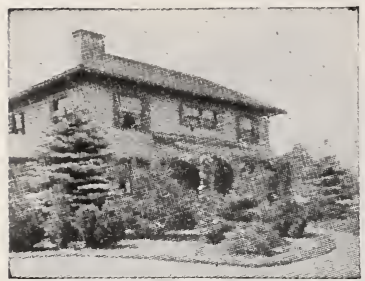

Evergreen Planting

In handling and planting evergreens never allow the roots to become dry for an instant. Their juices are resinous, and when once dry, water has no power to restore them; dip the roots in "grout" or very thin mud, and plant quickly; cover the roots with fresh soil and with a heavy piece of wood beat the earth solid over them. Fill up and pound again, and finish by bringing

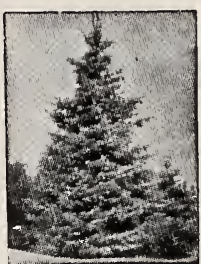

Spruce

fresh loose earth about the tree with a hoe. No wind can now bend the tree about so as to break the tender rootlets as fast as formed.

Use Scotch P'ine, White Spruce, Norway Spruce, and White Pine for high screens, and Arbor Vitae or Red Cedar for low ones.

ARBOR VITAE (American)-This plant is, all things considered, the finest evergreen for hedges. It is very hardy and easily transplanted, few plants failing if properly handled. It grows rapidly and with little care, or rather by easy management, it soon forms a most beautiful hedge, very dense and perfectly impervious to the sight. It is never planted to turn stock, but it forms a most desirable and ornamental screen to divide the lawn from other grounds.

ARBOR VITAE ((Pyramidalis)superb, new and hardy sort, of very compact habit; much better than the Irish Juniper, and grown in a perfect column. Largely planted in cemeteries, owing to the small amount of space it occupies. This is perhaps the most valuable Arbor Vitae in cultivation.

BALSAM FIR-A handsome, compact erect, pointed tree, with short, soft leares, which are dark green above, silvery beneath, a good grower.

IEMLOCK-An elegant pyramidal tree, wi t h drooping branches and delicate dark foliage, like that of the Yew; distinct from all other trees. It is a beautiful lawn tree and makes a highly ornamental hedge.

IRISH JUNIPER - Very erect and tapering in its growth, forming a column of deep green foliage; a pretty little tree or shrub, and a general favorite for its beauty and hardihood.

NOIRIVAY SPRUCE-A lofty, elegant tree of perfect pyramidal habit, exceedingly picturesque and beautiful. One of the best evergreens for windbreaks.

PINE AUSTRIAN or BLACK-A remarkably robust, hardy, spreading tree; leaves long, stiff, dark green; growth rapid; valuable for this country.

PINE, SCOTCH-Is one of the most rapid growers while young, one of the best for shelter planting in the West. It will make the best windbreak in the least time of any; it is a very valuable species

PINE, IVIITE-One of the best ever-

me greens. The foliage is a warm, light green, often with a blush tinge. The leaves, in fives, are three or four inches long, soft and delicately fragrant. It does not grow as rapidly the first few years as some, wut after being planted eight or ten years it is the most rapid grower of all our evergreens.

RED CEDAR-A well known tree with fine deep green foliage; variable in its growth; suitable $f$ o $r$ ornamental hedges.

SPRUCE, COLORADO BLUE This species has been tested at various points on $t h$ prairies of the West and Northwest wi th perfect success, and during a tempera-

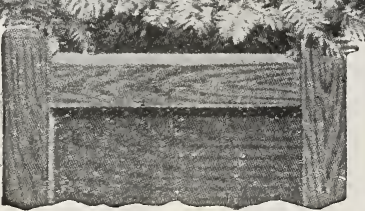

Spruce, Colorado Blue SPRCCE, WIITE-A tall tree with compact branches and light green foliage. Very handsome.

Our evergreens are given special care, handled carefully and transplanted frequently, so there is no danger in moving them from our nurseries. Each tree is planted so that it grows symmetrically and develops into a shapely specimen. 


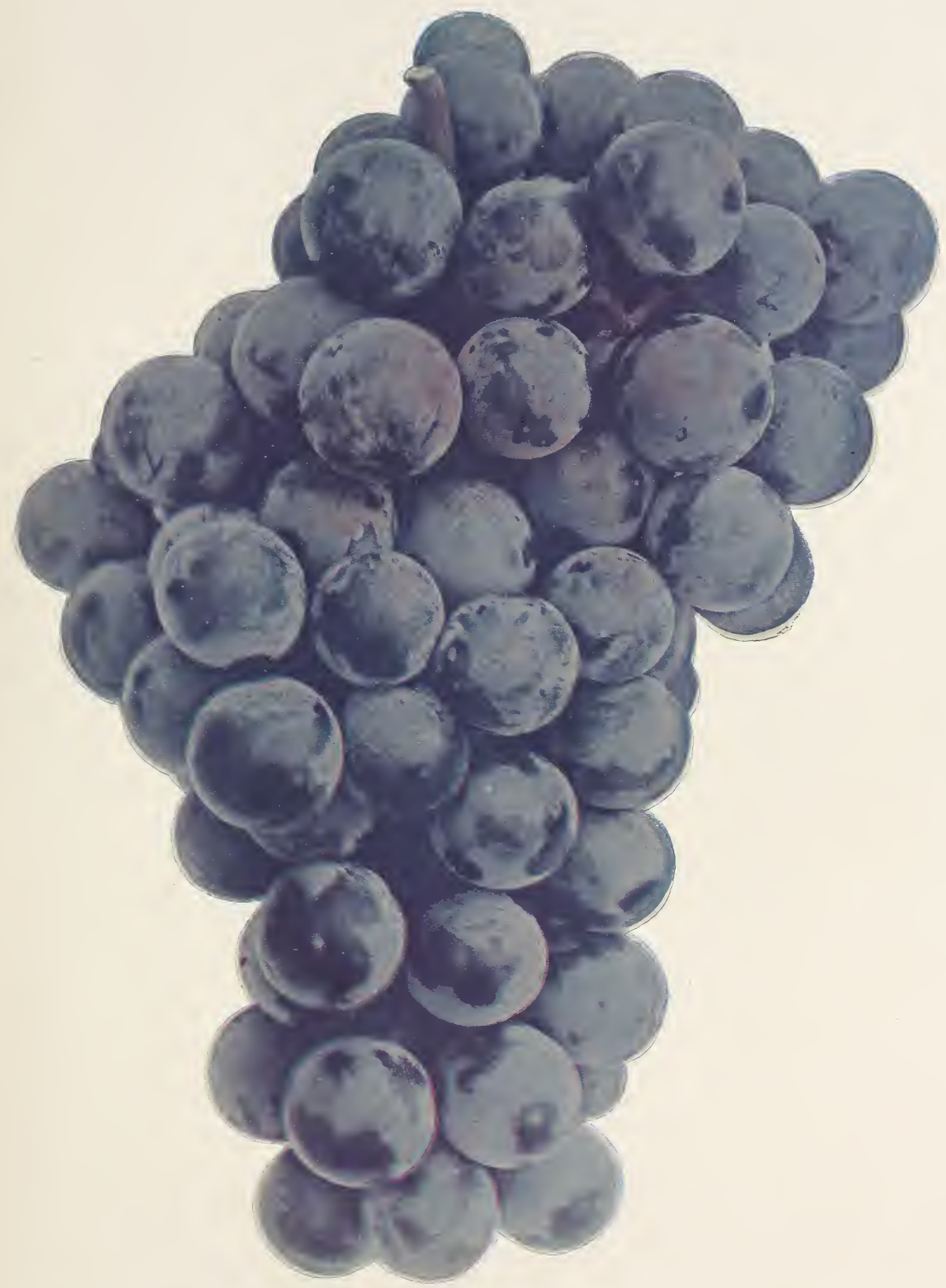

Concord Grapes. The standard for productireness and hardiness all over the country. Considered the most satisfactory variety for all purposes. 


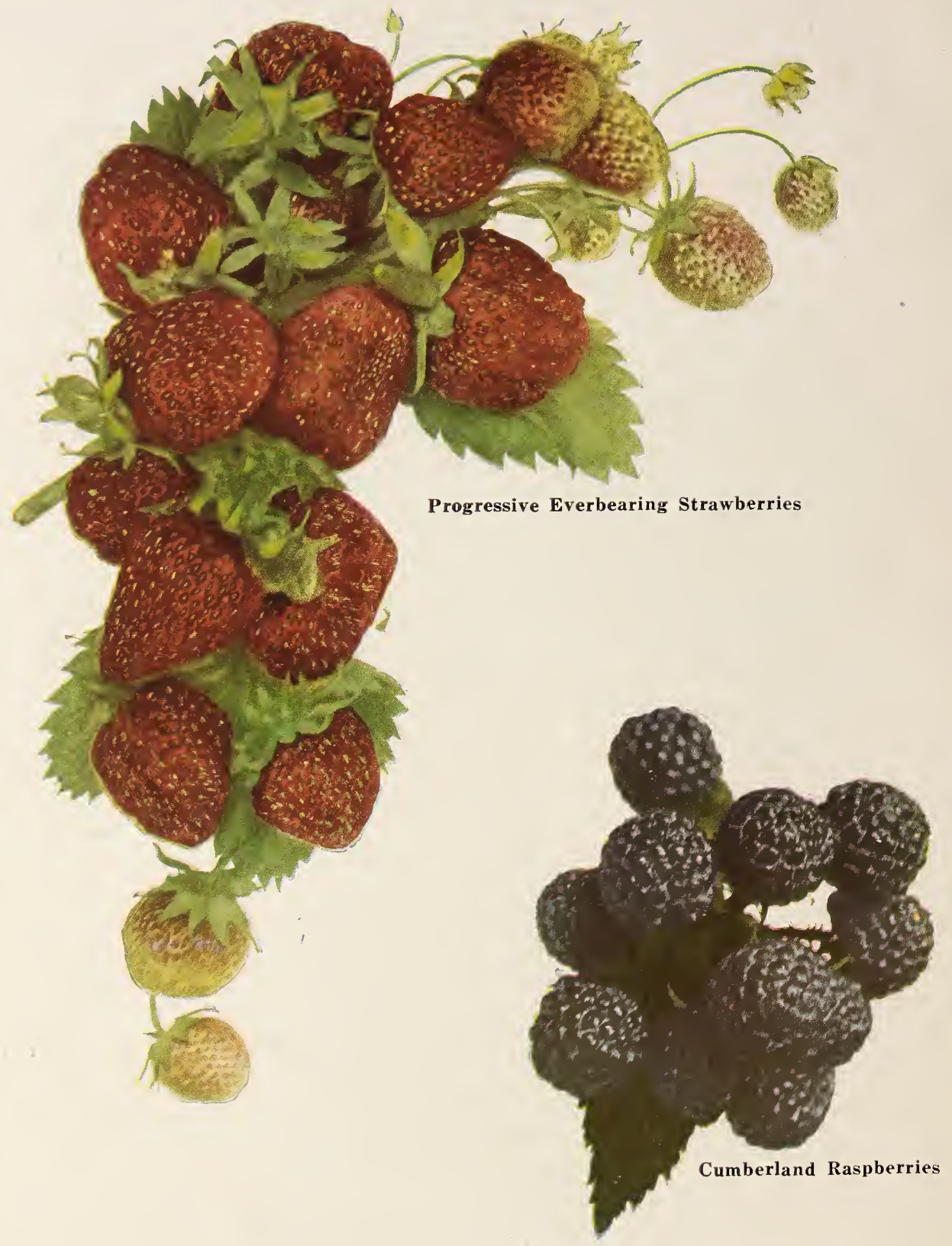

